\title{
LEUNGITEUN \\ KACAPI DALAM KAWIH WANDA ANYAR
}

\author{
SKRIPSI \\ KARYA SENI \\ KACAPI KAWIH WANDA ANYAR
}

Untukmemenuhisalahsatusyaratujianakhir

Program StudiSeniKarawitan

Fakultassenipertunjukan ISBI Bandung

\author{
OLEH \\ UJANG SAAD \\ 15123018
}

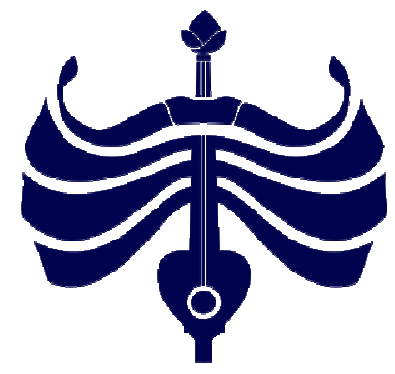

PROGRAM STUDI KARAWITAN

FAKULTAS SENI PERTUNJUKAN

INSTITUT SENI BUDAYA INDONESIA BANDUNG 2019 


\begin{abstract}
ABSTRAK
Sajian pada garapan ini merupakan ungkapan ekspresi yang dibalut dengan sebuah sajian musik tradisi dengan mengangkat cerita dari pengalaman pribadi penyaji sebagai tokoh utama. Bentuk penyajian ini tetap dalam nuansa kawih wanda anyar. Namun, terdapat beberapa kreativitas musik pada berbagai pola tabuh kacapi kawih sebagai komponen utama penyaji pada tugas akhir ini.

Karya ini berjudul "Leungiteun" judul ini diambil sesuai dengan alur cerita yang dibawakanya itu kehilangan cinta atau kasih sayang seseorang yang dicintai melalui beberapa ornament-ornamen kacapi kawih tertentu. Diantaranya sintreuk toel, dijambret, diranggeum, dan dijeungkalan.

Teori yang digunakan pada sajian ini menggunakan kreativitas yang dikemukakan oleh Tardi Ruswandi pada bukunya yang berjudul "Bahan ajar kacapi". Penyaji menggambil beberapa teori tentang teknik dan tahapan-tahapan pembelajaran kacapi dengan baik dan benar.
\end{abstract}

Kata Kunci :kacapi, kawih wanda anyar 


\title{
HALAMAN PERSETUJUAN
}

\author{
SKRIPSI KARYA SENI
}

LEUNGITEUN

KACAPI KAWIH WANDA ANYAR

\author{
Diajukan oleh \\ UJANG SAAD \\ 15123018
}

Disetujui oleh pembimbing untuk mengikuti Ujian Akhir

Pada program studiSeniKarawitan

Fakultas Seni Pertunjukan ISBI Bandung

Bandung, 29 Juli 2019

Pembimbing I Pembimbing II

Mustika Iman Zakaria, M. Sn.

NIP. 1983312092014041001
Asep Nugraha, M.Sn.

NIP.198007052008011021

Mengetahui,

Program StudiSeniKarawitan

Dr. Lili Suparli, M.Sn.

NIP. 196706201997031002 


\title{
HALAMAN PENGESAHAN \\ SKRIPSI KARYA SENI
}

\section{LEUNGITEUN}

\author{
Oleh \\ UJANG SAAD \\ 15123018
}

Telah dipertahankan di depan dewan penguji Melalui Sidang Tugas Akhir

Pada 29 Juli 2019

Susunan Dewan Penguji

Ketua Dewan Penguji : Dr. Lili Suparli,M.Sn.

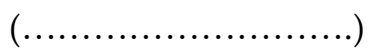

PengujiUtama $\quad$ : $\quad$ Dr. M. Yusup Wiradiredja, M.Hum.

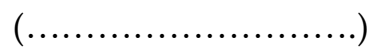

Anggota $\quad$ : $\quad$ Dr. Tardi Ruswandi, S. Kar., M.Hum.

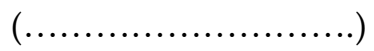

Pembimbing/anggota Mustika Iman Zakaria, M.Sn.

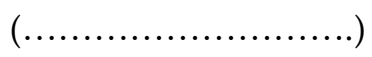

Pertanggung jawaban tertulis karya seni ini telah disahkan sebagai

Salah satu persyaratan untuk memperoleh gelar Sarjana Seni Fakultas Seni Pertunjukan, Institut Seni Budaya Indonesia (ISBI) Bandung

Bandung, 29 Juli2019

Mengetahui

Ketua Jurusan,

Program Studi SeniKarawitan

Dekan

Fakultas Seni Pertunjukan

Dr. Lili Suparli, M.Sn.

NIP. 196706201997031002
Dr. Lilis Sumiati, S.Sen.,M.Sn

NIP. 196711141993022001 


\section{PERNYATAAN}

Saya menyatakan bahwa SKRIPSI KARYA SENI dengan judul: "LENGITEUN" beserta seluruh isinya adalah benar-benar karya saya sendiri. Saya tidak melakukan penjiplakan atau pengutipan atau tidakan plagiat melalui cara-cara yang tidak sesuai dengan etika keilmuan akademik. Saya bertanggungjawab dengan keaslian karya ini dan siap menanggung resiko atau sanksi apabila dikemudian hari ditemukan halhal yang tidak sesuai dengan pernyataan ini.

Bandung, 29 Juli 2019

Yang membuat pernyataan

$$
\text { Materai }
$$
6000

UJANG SAAD

NIM.15123018 


\section{KATA PENGANTAR}

Puji dan syukur penyaji panjatkan kehadirat Allah SWT yang telah memberikan rahmat dan karunianya sehingga penyaji dapat menyelesaikan proposal Tugas Akhir yang berjudul "Leungiteun" ini dengan baik. Skripsi ini dibuat sebagai salah satu syarat tugas akhir program sarjana S1 Program Studi Karawitan Fakultas Seni Pertunjukan Institut Seni Budaya Indonesia (ISBI) Bandung.

Dalam menyelesaikan skripsi Tugas Akhir ini, tentu banyak sekali hambatan dan kekurangan. Namun dengan adanya dorongan dan bantuan dari semua pihak, akhirnya skripsi ini terselesaikan dengan baik. Maka dari itu penyaji mengucapkan benyak terima kasih kepada seluruh pihak yang telah membantu dalam penyelesain skripsi ini. Adapun pihak yang telah membantu penyaji dihaturkan ucapan terima kasih kepada:

1. Bapak Dr. Lili Suparli, M.Sn.., selaku Ketua Jurusan Program Studi Karawitan ISBI Bandung.

2. Bapak Dr. Tardi Ruswandi, S.Kar, M.Hum., Selaku Dosen Pengajar Kacapi pada Program studi Karawitan ISBI Bandung. 
3. Kedua orang tua, ibunda dan ayahanda tercinta yang selalu memberi dukungan, motivasi serta doa, sehingga penyaji terdorong untuk selalu memberikan yang terbaik.

4. Kakak dan adik tercinta yang selalu memberi dukungan.

5. Seluruh Mahasiswa Seni Karawitan Sunda ISBI Bandung, khususnya mahasiswa kelas Penyajian yang sama-sama berjuang dan selalu memberi support yang baik.

6. Seluruh Pendukung Karya

7. Teman-teman seperjuangan angkatan "MUNDINGLAYA" 2015

Penyaji berharap semoga dengan adanya skripsi ini, biasa menjadi acuan ke depannya untuk menghasilkan karya yang lebih baik bagi generasi muda yang akan datang. Selain itu penyaji berharap kritikan dan saran yang membangun dari seluruh pembaca umumnya.

Bandung, 29 Juli 2019

\section{UjangSaad}

15123018 


\title{
DAFTAR ISI
}

\begin{abstract}
Abstrak ............................................................ ii

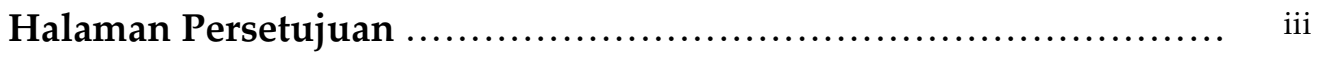

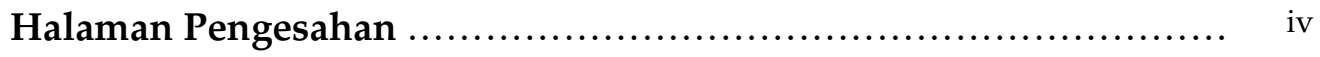

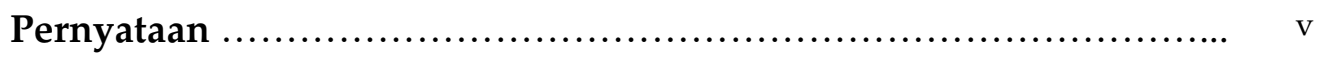

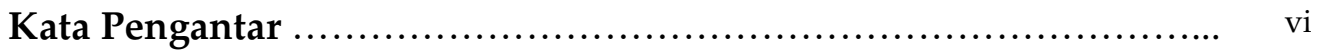

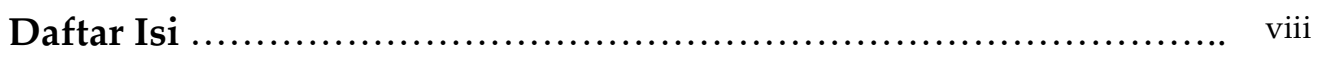

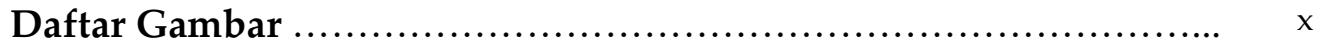

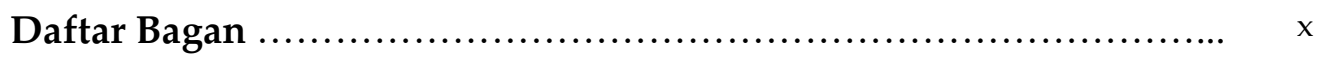

Catatan Pembaca
\end{abstract}

BAB I Pendahuluan .............................................. 1

1.1. Latar Belakang Gagasan ....................................... 1

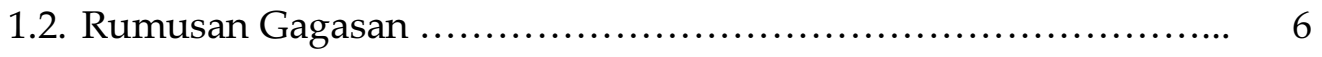

1.3. Tujuan dan Manfaat ......................................... 7

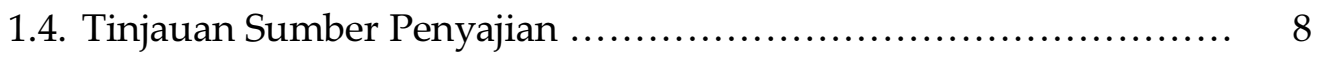

1.5. Landasan Teori Karya Seni .................................. 10

1.6. Metode Penyajian ......................................... 12

BAB II Proses Garap .......................................... 13 
2.1. Tahapan Eksplorasi ........................................ 13

2.2. Tahapan Evaluasi $\ldots \ldots \ldots \ldots \ldots \ldots \ldots \ldots \ldots \ldots \ldots \ldots \ldots \ldots \ldots \ldots \ldots . . \ldots \ldots \ldots$

2.3. Tahapan Komposisi ........................................ 15

BAB III Deskripsi Dan Pembahasan Karya Seni .................. 18

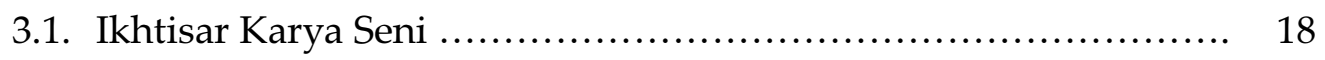

3.2. Sarana Presentasi ........................................... 19

3.2.1. Lokasi Penyajian $\ldots \ldots \ldots \ldots \ldots \ldots \ldots \ldots \ldots \ldots \ldots \ldots \ldots \ldots \ldots . \ldots \ldots$

3.2.2. Penataan Pentas ..................................... 20

3.2.3. Instrumen yang Digunakan $\ldots \ldots \ldots \ldots \ldots \ldots \ldots \ldots \ldots \ldots \ldots . . \ldots \ldots \ldots$

3.2.4. Kostum ........................................... 22

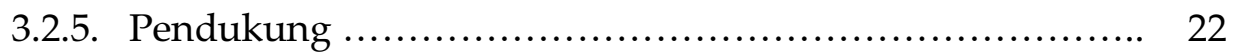

3.3. Konsep Garap .......................................... 24

3.4. Bentuk Karya ............................................ 25

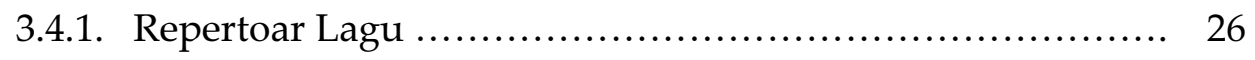

1. Bubuka ........................................... 26

2. Dua Saati ......................................... 30

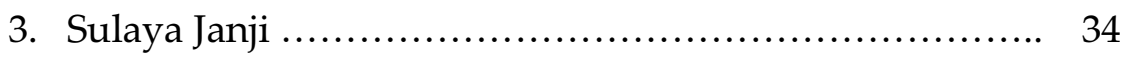

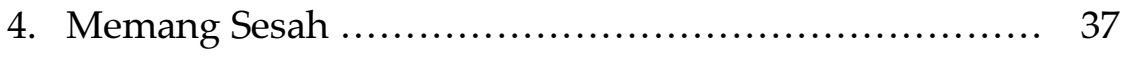

5. Kuring Leungiteun ............................... 40 
BAB IV Kesimpulan $\ldots \ldots \ldots \ldots \ldots \ldots \ldots \ldots \ldots \ldots \ldots \ldots \ldots \ldots \ldots \ldots \ldots, 52$

Daftar Pustaka ..................................................... 54

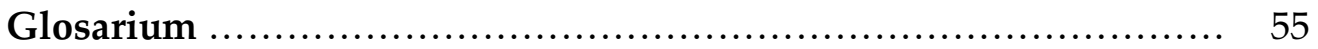

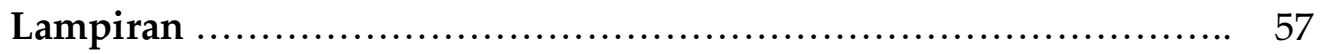

\section{DAFTAR GAMBAR}

Gambar 1 Layout panggung TA Leungiteun ........................ 22

Gambar 2 kostum TA Leungiteun ................................. 23

\section{DAFTAR BAGAN}

Bagan 1 Aplikasi Teori Garap dalam penyajian TA Leungiteun ........ 11

Bagan 2 Metode Penyajian TA Leungiteun ......................... 12 


\section{BAB I}

\section{PEMBAHASAN}

\subsection{Latar Belakang Gagasan}

Pada awalnya penyebutan kawih wanda anyar ditujukan pada garapan karya karawitan yang diciptakan Koko Koswara (Mang Koko)ㄹ, karena pada saat itu karya yang teraktualisasikan terkesan berbeda dengan gaya kawih klasik. Seiring dengan perjalanan waktu ternyata karya Mang Koko mampu mengkristal, mentradisi, dan melewati perjalanan ruang dan waktu yang panjang. Pada akhirnya penyebutan wanda anyar menjadi genre tersendiri dalam percaturan karawitan Sunda, berdampingan dengan seni tradisi lain yang telah mapan pada masyarakat Sunda.

Penamaan wanda anyar tersusun atas dua buah kata, yakni wanda dan anyar. Kamus Bahasa Sunda Belanda (Soendaneesch-Hollandsch Worrdemboek) yang ditulis oleh Coolsma mencantumkan wanda sebagai pootisch voor roepa, gestalte, yang artinya sebutan untuk rupa, perawakan, dan bentuk (Coolsma, 1913:712); sedangkan anyar dalam Kamus Sunda-

\footnotetext{
${ }^{1}$ Koko koswara lahir di Indihiang Tasikmalaya, Jawa Barat, tangggal 24 November 1915.
} Ia adalah tokoh Karawitan Sunda yang terkenal dengan genre wanda anyar (Tardi Ruswandi, Kawih Sunda karya Mang Koko: 2017:2). 
Indonesia (1985) diartikan sebagai baru, mutakhir, dan gres (Maman

Sumantri, dkk, 1985:66)². Dengan demikian, istilah wanda anyar sebagai seni pertunjukan karawitan Sunda merupakan penyebutan wajah baru atau sebuah sebutan untuk garapan karawitan gaya baru (apabila dibandingkan dengan seni karawitan tradisi yang telah ada pada awal kemunculannya), berbeda dengan gaya klasik (Geri Kurnia, 2017:1).

Waditra yang lajim digunakan dalam penyajian wanda anyar yaitu: Gamelan pelog/salendro, kacapi siter, kendang, suling, rebab, perkusi, biola, dan goong. Selain itu seniman ada yang difungsikan sebagai vocalist (juru sekar) dan sebagai juru pirig. Pertalian dari sajian vokal dan instrumen (waditra) pada wanda anyar menunjukan bahwa bentuk sajiannya adalah sekar gending. Sekar dihasilkan sajian vokal manusia, sedangkan gending dihasilkan bunyi waditra atau alat musik. ${ }^{3}$

Dari beberapa alat atau waditra yang lazim digunakan untuk mengiringi sajian wanda anyar, terdapat instrumen kacapi yang menjadi instrument kesayangan Mang Koko. Tidak heran, Mang Koko merupakan

\footnotetext{
${ }^{2}$ Penulis (Penyaji) menggunakan dua kamus bahasa Sunda, dikarenakan istilah wanda hanya ditemukan dalam Kamus terbitan Belanda yang ditulis Coolsma (1913). Pada kamus bahasa Sunda yang lain istilah wanda sangat sulit ditemukan. Namun dalam kamus tersebut tidak ditemukan istilah anyardalam susunan kosa kata. Akhirnya istilah anyar ditemukan dalam buku Kamus Bahasa Sunda-Indonesia terbitan Departemen Pendidikan dan kebudayaan yang ditulis Maman Sumantri, dkk (1985).

${ }^{3}$ Kekaryaan wanda anyar Mang Koko juga pernah berkolaborasi dengan pencipta tari Sunda, Enoch Atmadibrata dalam gending Hujang Munggaran, di mana Enoch menjadi penata tarinya tahun 1967. Tari Hujan Munggaran dengan penata gending Koko Koswara, dipentaskan siswa SMKI di Gedung Merdeka Bandung, di kediaman Gubernur Jakarta Ali Sadikin, di Banjar Ciamis dengan karcis yang laku terjual (Komala, 2015:22).
} 
seniman yang sangat mampuni dalam penguasaan $\mathrm{kacapi}^{4}$. Sering kali ia menampilkan karya-karya yang diiringi petikan kacapi, menyajikan aransemen khusus yang sengaja diciptakannya. ${ }^{5}$ Karya-karya yang dihasilkan Mang Koko dalam permainan kacapi wanda anyar, selain berupa aransemen dan iringan vokal yang dinamis, juga mampu membuat metode pembelajaran kacapi (Ruswandi, 2013:100). Metode ini selain dapat menuntun proses belajar kacapi secara mandiri, juga mampu melahirkan generasi penerus pemain kacapi gaya Koko Koswara (Nugraha, 2015:139).

Kacapi dengan aransemen khusus yang diciptakan oleh Mang Koko, menghasilkan gaya tabuhan yang disebut kacapi kawih wanda anyar (Ruswandi 2013). Jenis kacapi yang digunakan adalah kacapi siter. Kacapi

${ }^{4}$ Sajian kacapi dalam Khasanah karawitan Sunda terbagi menjadi beberapa macam, yaitu kacapi biola, kacapi modern, kacapi suling, dan kacapi tarawangsa. Perbedaan dari beebrapa jenis kacapi tersebut adalah kacapi biola yang merupakan bahan pergelaran dengan memperagakan kacapi dan biola, kacapi moderen merupakan sebutan untuk ditata dalam tangga nada diatonis dan memainkan lagu dalam tangga nada diatonis, kacapi suling merupakan perangkat sunda yang terdapat hampir disetiap daerah yang didalamnya dibantu dengan alat musik suling. Sedangkan kacapi tarawangsa adalah bentuk seni pertunjukan yang merupakan perpaduan antara tabuhan atau petikan kacapi dengan gesekan tarawangsa.

${ }_{5}^{5}$ Dalam menyiptakan permainan kacapi wanda anyar, motif-motif petikannya bersumber pada pengalaman Koko semasa kanak-kanak dan remaja, yang akrab dengan lingkungan pendidikan Belanda berikut musiknya. Tidak heran jika arransemen petikan kacapi gaya Koko, banyak dipengaruhi harmoni "arpegio" dan irama "mars." Selain itu, dengan cerdas Koko meluruhkan fenomena triakord diatonik yang dimasukkan dalam permainan kacapinya. Akan tetapi triakord diatonik tersebut ditutupi dengan nuansa tradisi karawitan Sunda, yaitu menonjolkan aksen kempyung: mi-la, da-ti, dan da-na, yang menjadi ciri khas petikan kacapi gaya Koko. Oleh sebab itu, sekalipun dalam kreativitasnya dipengaruhi musik Barat, namun alunan melodi yang diciptakan Koko tetap bernuansa karawitan Sunda (Nugraha, 2015:139). 
siter adalah alat petik (waditra) berbentuk semacam kotak persegi panjang, yang senarnya berjumlah 18 sampai dengan 20 atau lebih (Ruswandi, 2008:3).

Dewasa ini pertunjukan kawih wanda anyar dapat ditemui pada acara seperti event seremonial, pemerintahan, maupun acara-acara pernikahan dan khitanan. Penyajiannya kawih wanda anyar tanpa instrumen gamelan, biasanya diiringi instrumen lengkap yang terdiri atas kacapi, suling, kendang, rebab dan goong. Dari beberapa waditra pengiring sajian kawih wanda anyar, penyaji mengapresiasi bahwa waditra kacapi merupakan waditra yang sangat dominan pada saat difungsikan mengiringi kawih wanda anyar. Dominasi tersebut dikarenakan kacapi memainkan 3 (tiga) fungsi utama dalam iringan yaitu: amardawa lagu (pembawa melodi lagu), arkuh lagu (pembawa kerangka lagu), dan pengatur ancaran wirahma (pengatur tempo dan irama lagu).

Dalam rumpun kawih wanda anyar terdapat beberapa unsur musikal seperti gending berupa melodis permainan kacapi yang difungsikan Mang Koko menjadi identitas lagu, garap orkestrasi antara instrumen dengan vokal, serta yang paling utama adalah rumpaka atau isi lagu' ${ }^{6}$ Secara konvensional dalam konteks tradisi, kacapi berfungsi sebagai instrumen

\footnotetext{
${ }^{6}$ Rumpaka pada lagu merupakan media penyampai pesan yang paling mudah diterima oleh audiens melalui juru kawih (vokalis).
} 
pengiring pendukung vokal sehingga persentasi vokal mencapai kedudukan yang paling vital dalam hal penyampaian isi atau pesan suatu lagu. Tidak heran jika permainan kacapi harus mampu menyelami struktur dan makna yang terkandung dalam teks lagu. Dengan begitu permainan kacapi dan juru kawih (sebutan untuk vokalis pada wanda anyar) akan menjadi satu kesatuan yang utuh.

Mustika Iman Zakaria, dosen Prodi Karawitan Fakultas Seni Pertunjukan ISBI Bandung, pengajar mata kuliah kacapi kawih, menyatakan pentingnya seorang pemain kacapi kawih untuk mampu menyelami kedalaman makna, isi, dan pesan yang terkandung dalam suatu lagu yang disajikan ketika dipertunjukkan. Ia mengistilahkan kacapi bebeng untuk pemain kacapi yang tidak mampu mencapai tingkatan itu.

Oleh karena itu, adanya pendapat agar pemain kacapi dapat memenuhi kompentensi di atas, menjadi dasar alasan bagi penyaji, agar bisa untuk mengejawantahkannya. Momentum yang dipandang tepat untuk aktualisasi bagi penyaji adalah pada saat ujian Tugas Akhir (TA) mahasiswa Prodi Karawitan Gelombang I tahun 2019. Hal ini beralasan mengingat penyaji merupakan mahasiswa tingkat akhir yang memilih minat kompetensi Tugas Akhir penyajian kacapi kawih wanda anyar. 
Tentunya agar kompetensi memainkan kacapi tidak bebeng, maka dalam sajian Tugas Akhir rencananya dibawakan lagu-lagu tema cinta dengan penggalian fenomena emosional psikologis seperti senang, marah, takut, dan sedih. Persaan-perasaan yang terkandung dalam lagu dituangkan ke dalam bentuk sajian pertunjukan di atas panggung. Adapun penyaji sebagai pemain kacapi kawih wanda anyar melalui reportoar lagu yang telah dipilih akan menyusun penyajian kacapi sesuai dengan gramatika pertunjukan.

Adapun gramatika pertunjukan tersebut merupakan hubungan struktur penyajian yang didalamnya terkait dengan pemilihan dan penempatan reportoar sesuai dengan tema yang diusung dalam satu pertunjukan. Konkritnya penyaji menunggangi tema suka-duka romantika percintaan dalam lagu agar dihayati dan diselami ke dalam penyajian kacapi. Pendek kata, antara penyaji (kacapi) dengan juru kawih menjadi satu kesatuan dalam mengkomunikasikan pesan-pesan yang terkandung dalam setiap lagu yang dibawakan. Disinilah keterampilan penyaji sebagai pemain kecapi dapat teruji. Berkaitan dengan apa yang telah disampaikan, penyaji akan mengusung judul "Leungiteun" Arti dari judul ini adalah kehilangan. Sebuah pesan yang biasanya diungkapkan ketika ada seseorang kehilangan sesuatu. 


\subsection{Rumusan Gagasan}

Dalam penyajian ini, judul yang diambil adalah "Leungiteun" sebagai representasi karya yang diangkat dari pengalaman pribadi. Penyajian yang mengandung konsep untuk berbagi pengalaman, dalam menceritakan kisah cinta antara sepasang kekasih yang sedang dilanda asmara, mulai dari mereka bertemu, sampai timbulnya perasaan saling menyukai dan akhirnya terjadi perpisahan yang menjadi akhir cerita. Penyajian ini dibawakan melalui iringan kacapi kawih wanda anyar yang dimainkan sendiri oleh penyaji dengan mengetengahkan beberapa judul lagu yang sesuai dengan konsep. Secara keseluruhan, sajian penyaji sebagai pemain instrument (kacapi) dibantu dengan keberadaan personil pendukung yang memainkan beberapa alat musik lainnya.

\subsection{Tujuan dan Manfaat}

\section{Tujuan}

- Mempresentasikan bentuk sajian kacapi kawih wanda anyar yang merupakan penggabungan dari gaya Mang Koko-an yang diinterpretasi dengan gaya sajian yang dibuat oleh penyaji.

- Menciptakan sebuah inovasi dan kreativitas dalam bentuk sajian kawih agar dapat menjadi nilai dalam sajian tugas akhir ini. 


\section{Manfaat}

- Dapat memberikan suguhan kepada apresiator dalam sajian kawihWanda Anyar yang dikemas melalui kreativitas penyaji dantolok ukur penyaji dalam menguasai kacapi kawih wanda anyar

- Dapat dijadikan referensi atau gagasan awal dalam mengembangkan garap kawih Wanda Anyar.

\subsection{Tinjauan Sumber Penyajian}

Dalam mencari data, Penyaji menggunakan beberapa referensi yang diperoleh dari buku dan dari dosen pengajar di jurusan karawitan. Penyaji juga melakukan wawancara kepada dosen pengajar dalam mata kuliah spesialisasi alat petik kacapi. Selain itu penyaji mendapatkan sumber dari Mp3, dan kaset-kaset rekaman. Adapun sumber yang penyaji jadikan rujukan terdiri atas dua kategori, yaitu:

1. Narasumber

a. Tardi Ruswandi, dosen alat petik (kacapi kawih wanda anyar) di Insitut Seni Budaya Indonesia (ISBI) Bandung, dari beliau penyaji mendapatkan teknik dasar menabuh kacapi, pola tabuh, cacarakan, dan teknik instrumen untuk bahan materi sajian. 
b. Mustika Iman Zakaria. merupakan dosen pengajar program keahlian alat petik kacapi kawih di Prodi Karawitan, Fakultas Seni Pertunjukan Insitut Seni Budaya Indonesia (ISBI) Bandung. Dari beliau penyaji mendapatkan konsep untuk tugas akhir.

c. Sofyan Triyana,seorang penggiat/arranger kacapi kawih wanda anyar yang juga merupakan alumni Prodi Seni Karawitan ISBI Bandung yang sekarang sedang menempuh kuliah S2. Beliau banyak membantu pengajaran intro-intro lagu penyaji yang akan dibawakan di Tugas Akhir (TA).

d. Ary Haryanto, merupakan mahasiswa program studi karawitan di Insitut Seni Budaya Indonesia (ISBI) Bandung. Beliau banyak membantu dalam pengajaran pirigan di setiap lagu-lagu yang akan dibawakan oleh penyaji dan turut serta membantu mendukung dalam bidang kacapi.

e. Tiarani Putri Irmayadi, merupakan pecinta seni yang ikut serta membantu memberi masukan dalam konsep garap dan penulisan. Serta turut membantu mendukung dalam bidang vokal.

f. Panji Triyadi, seorang penggiat/arranger kacapi kawih pada wanda anyar yang juga merupakan alumni Prodi Seni Karawitan ISBI 
Bandung. Beliau banyak memberi masukan mengenai beberapa motif pirigan dalam lagu Sulaya Jangji yang akan dibawakan.

g. Ilham Firmansyah, seorang penggiat/arranger kacapi kawih pada wanda anyar yang juga merupakan mahasiswa Program studi Seni Karawitan ISBI Bandung. Dari beliau penyaji mendapatkan motif pirigan dalam lagu MemangSesah.

2. Sumber Audio

Sumber Audio Visual yang penyaji gunakan dalam penyajian ini sebagai sumber kajian, yaitu:

1. Audio Mp3 lagu Dua Saati Nano S.

2. Audio Mp3 lagu Sulaya Jangji Mang Koko

3. Audio Mp3 lagu Memang Sesah Nano S

4. Audio Mp2 Kuring lengiteun Mohamad Yusuf Wiradiredja

\subsection{Landasan Teori Karya Seni}

Rencana karya penyajian tugas akhir yang diusung oleh penyaji dengan judul Leungiteun pada dasarnya adalah penyajian kacapi dalam kawih Wanda Anyar yang menampilkan bentuk keseluruhan (musik) yang berbeda. Namun tidak lepas dari kaidah atau konvensi yang telah ada. 
Hal ini menandakan adanya keberadaan 'garap' yang diejawantahkan penyaji.

Teori Garap pada entitas Karawitan didengungkan oleh Rahayu Supanggah, melalui Desertasi yang dipertahankannya di Université de Paris VII di Perancis pada tahun 1985. Teori Garap Supanggah dikutip sebagai berikut:

Garap yaitu interpretasi, imaginasi, bekal keterampilan, vokabuler, serta kemampuan, dan kreativitas senimannya. Garap merupakan rangkaian beberapa aktivitas yang membentuk sebuah sistem. secara ringkas garap terbentuk dan bekerja dengan ketersediaan: materi garap, penggarap, alat untuk menggarap, sarana garap, penentu garap, dan penunjang garap (Supanggah, 2015, 455-456).

Aplikasi Teori Garap dengan penyajian TA Leungiteun merupakan penerapannya yang dilakukan oleh penyaji melalui garap terhadap kacapi kawih yang ditampilkan, dan imbasnya terhadap sajian Wanda Anyar pada saat pertunjukan di atas panggung. Implementasi penerapan teori garap ini, tentunya nanti berjalan pada saat proses pencarian dan eksplorasi bersama dengan personil pendukung dan atas tuntunan para pembimbing. Namun mengenai ketersedian terwujudnya 'suatu garap' pada Karawitan seperti yang diutarakan Supanggah di atas, telah terpenuhi. 


\begin{tabular}{|c|c|}
\hline Materi Garap & $\begin{array}{l}\text { 1. Kacapi kawih } \\
\text { 2. Wanda anyar }\end{array}$ \\
\hline Penggarap & $\begin{array}{l}\text { Penyaji dibantu personil pendukung } \\
\text { pertunjukan TA }\end{array}$ \\
\hline $\begin{array}{l}\text { Alat untuk } \\
\text { Menggarap }\end{array}$ & $\begin{array}{l}\text { Instrumen alat musik pada genre dan wanda } \\
\text { anyar }\end{array}$ \\
\hline Sarana Garap & $\begin{array}{l}\text { Vokabuler garap pada kacapi dan sajian wanda } \\
\text { anyar yang diolah berdasarkan unsur tematik }\end{array}$ \\
\hline Penentu Garap & $\begin{array}{l}\text { Tujuan dan fungsi garapan dilakukan. Pada } \\
\text { tataran ini adalah sebagai penentu Tugas } \\
\text { Akhir }\end{array}$ \\
\hline
\end{tabular}

Bagan 1. Aplikasi Teori Garap dalam penyajian TA Leungiteun

\subsection{Metode Penyajian}

Tentunya terdapat sejumlah cara yang diimplementasikan dalam menyajikan karya TA Leungiteun untuk dinilai sacara akademik oleh tim penilai Prodi Karawitan Fakultas Seni Pertunjukan ISBI Bandung. Metode tersebut menjadi fenomena yang diserap dan diaplikasikan oleh penyaji yang didukung para personil pertunjukan, berkaitan dengan produk karya seni yang akan dihasilkan dan ditawarkan ke dalam bentuk pertunjukan.

Dalam konteks seperti itu, terdapat proses yang diejawantahkan penyaji untuk ditanggapi dan diolah melalui proses eksplorasi, evaluasi, dan komposisi yang meliputi garap, karya karawitan wanda anyar sebagai 
perangkat penyajian, konsep dan teori yang diejawantahkan, serta notasi permainan instrumen. Bagan di bawah ini berupaya untuk memperjelas proses dari penerapan metode yang diterapkan .

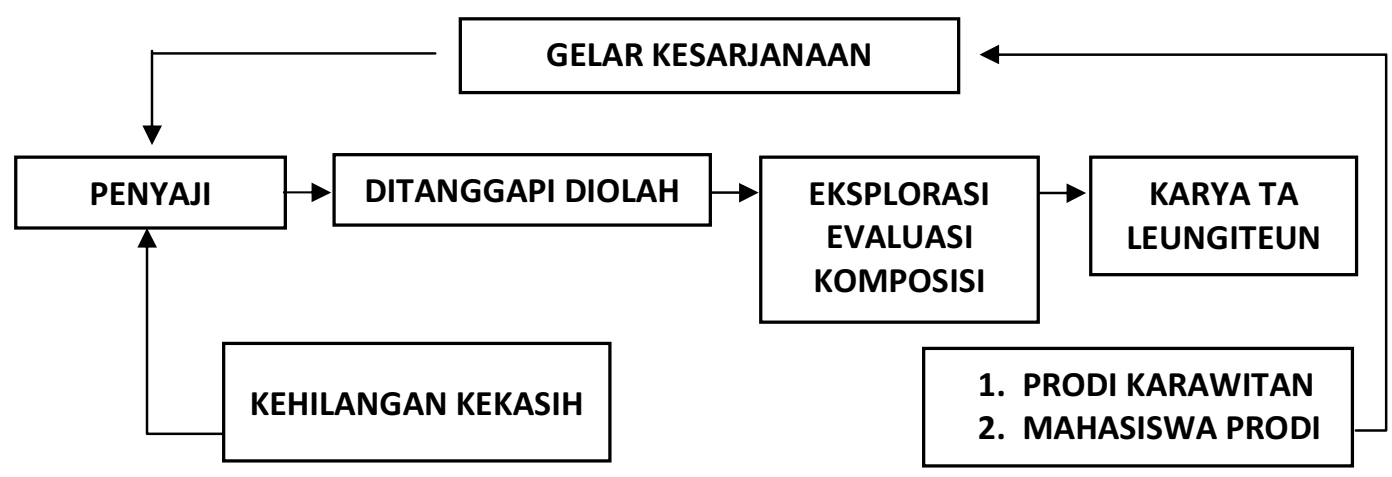

Bagan 2. Metode Penyajian TA Leungiteun 


\section{BAB II}

\section{PROSES GARAP}

Rencana karya penyajian Tugas Akhir yang diusung oleh penyaji dengan judul Leungiteun pada dasarnya adalah penyajian kacapi dalam kawih Wanda Anyar yang menampilkan bentuk keseluruhan (musik) yang berbeda, namun tidak lepas dari kaidah atau konvensi yang telah ada. Pada bab ini yang akan dibahas yaitu tahapan pelaksanaan proses garap dari awal proses hingga akhir pementasan. Dalam menggarap sebuah karya seni, terdapat beberapa tahapan yang tentunya bisa menunjang sebuah konsep garap agar sesuai dengan yang diinginkan. Tahapantahapan tersebut diawali dengan mengeksplorasi, evaluasi, dan komposisi.

\subsection{Tahapan Eksplorasi}

Pada tahap ini penyaji mengumpulkan berbagai macam data sesuai dengan kebutuhan penyaji dalam mengolah dan mengeksplorasi garapan seperti beberapa hal yang menjadi kebutuhan utama, di antaranya, penentuan tema, penentuan judul, penentuan konsep garap, teknik dan pola tabuh, hingga lagu-lagu yang akan dibawakan. 
Pada tahap awal yang dilakukan penyaji bersifat umum mengenai kacapi kawih wanda anyar dari berbagai macam teknik penjarian. Penyaji berapresiasi dan mengeksplor berbagai macam teknik serta pola tabuh kacapi. Setelah menemukan berbagai macam teknik serta pola tabuh kacapi, penyaji pun melanjutkan ketahap selanjutnya yaitu mencari teknik penjarian yang tepat serta melakukan penyadapan kepada beberapa seniman yang ahli di bidang kacapi kawih wanda anyar. Pada akhirnya penyaji akan mencoba untuk menyajikan hasil- hasil pembelajaran dan penyadapan tersebut untuk ditampilkan pada Tugas Akhir (TA).

Hal ini merupakan tahapan paling inti dalam proses penyaji dalam pembentukan garapan yang diusung penyaji. Dari mulai adanya arahanarahan dosen pembimbing hingga rampungnya proses yang akan dijadikan sebuah karya.

\subsection{TahapanEvaluasi}

Evaluasi merupakan kegiatan yang dilakukan berkenaan dengan proses untuk menentukan nilai dari suatu hal. Dari berbagai macam teori dengan pencarian data-data yang dibutuhkan penyaji, hingga akhirnya sampailah pada tahap evaluasi untuk mengukur seberapa besar 
kemampuan penyaji dalam mengolah data dan mengevaluasi kesesuaian data dengan konsep garap dan judul yang diusung.

Tahap evaluasi ini penyaji lakukan setelah menemukan adanya ide atau gagasan baru yang berhubungan dengan garapan ini. Tahap evaluasi ini sangat penting agar sesuai dengan konsep garap yang diinginkan.

\subsection{TahapanKomposisi}

Seni Pertunjukan merupakan sebuah karya seni pertunjukan yang disajikan langsung dihadapan penonton yang statis diam di satu tempat dengan mengetangahkan sebuah karya seni dalam bentuk audio visual. Dalam sebuah penyajian karya seni tentu memiliki konsep sesuai dengan tema dan judul yang diambil dan disesuaikan pula dengan adanya pendukung-pendukung alat musik, vokal, kostum, sound system, desain panggung dan lain-lain, yang akan menunjang keberhasilan seni pertunjukan sesuai dengan tema dan judul yang akan dibawakan.

Konsep garapan yang akan diambil pada pertunjukan kali ini menceritakan tentang pengalaman pribadi mengenai perjalanan seseorang yang patah hati karena cinta. Oleh karena itu lagu yang dibawakan sesuai dengan konsep tersebut adalah : 


\section{Dua Saati (Nano S.)}

Lagu ini menceritakan perjalanan seseorang yang dilanda asmara. Sesuai dengan konsep cerita yang diambil dalam garapan ini berawal dari pertemuan dan awalan percintaan seseorang.

2. Sulaya Jangji (Mang Koko)

Lagu ini menceritakan tentang seseorang yang memadu cinta kemudian ditinggalkan karena janji palsunya. Sesuai dengan konsep cerita yang diambil dalam garapan ini setelah adanya kebahagiaan karena cinta diakhiri oleh perpisahan dalam janji palsu.

3. Memang Sesah (Nano S)

Lagu ini menceritakan tentang seseorang yang sedang patah hati dan putus asa dalam mencari penggantinya. Sesuai dengan konsep cerita yang diambil dalam garapan ini setelah adanya perpisahan dengan orang dicintainya kemudian dia putus asa untuk mencari yang lebih baik. 


\section{Kuring Leungiteun (M.Yusuf Wiradiredja)}

Lagu ini menceritakan tentang seseorang yang sangat merasa kehilangan. Sesuai dengan konsep cerita yang diambil dalam garapan ini setelah putus asa kemudian dia terus merasa kehilangan dan belum bias melupakannya.

Lagu-lagu tersebut diaransemen ulang dalam musik nuansa cinta dan harmonisasi. Namun, aransemen tersebut tidak mengubah notasi lagu yang dibawakan. Lagu yang akan dibawakan berurutan sesuai dengan cerita dan dibawakan masing-masing dua putaran lagu secara berturut - turut. 


\section{BAB III}

\section{DESKRIPSI DAN PEMBAHASAN KARYA SENI}

\subsection{Ikhtisar Karya Seni}

Cinta adalah sebuah emosi dari kasih sayang yang kuat dan ketertarikan pribadi. Cinta juga dapat diartikan sebagai suatu perasaan dalam diri seseorang akibat faktor pembentuknya. Pendapat lainnya, cinta adalah sebuah aksi atau kegiatan aktif yang dilakukan manusia terhadap objek lain, berupa perhatian, kasih sayang, membantu, menuruti perkataan, dan mau melakukan apapun yang diiginkan objek tersebut.

Cinta antar pribadi menunjuk kepada cinta antar manusia. Bentuk ini lebih dari sekedar rasa kesukaan terhadap orang lain. Cinta antar pribadi bisa mencakup hubungan orang tua dengan anak, hubungan persahabatan, dan hubungan kekasih. Banyak orang yang mengungkapkan cinta melalui media atau cara lain yang diinginkannya. Hal tersebut tentu atas dasar pengalaman pribadi. Seperti penyaji yang akan mengungkapkan pengalaman cinta tersebut ke dalam bentuk sebuah sajian kawih wanda anyar yang berjudul "Leungiteun".

Setiap repertoar lagu dalam sajian ini, mewakili perjalanan cerita cinta penyaji. Dimulai dari menceritakan pertemuan dengan seorang 
perempuan, kemudian bersama menjalani cinta. Setelah sekian lama bersama, pada suatu ketika perempuan tersebut mengingkari janjinya sehingga memutuskan untuk pergi. Setelah perpisahan itu terjadi, pada akhirnya penyaji putus asa dengan kegagalan cintanya tersebut. Hal tersebut menjadi sebuah kenangan yang menyisakan kepedihan hati bagi penyaji. Sehingga lagu akhir dari sajian ini penyaji memilih lagu leungiteun yang berarti kehilangan.

\subsection{Sarana Presentasi}

\subsubsection{Lokasi penyajian}

Pertunjukan tugas akhir karya seni kacapi kawih wanda anyar yang berjudul "Leungiteun" ini dilaksanakan pada:

Hari/tanggal : Kamis / 21 Juni 2019

Tempat : : Gedung Kesenian Sunan Ambu

Institut Seni Budaya Indonesia (ISBI) Bandung

Alamat : Jl. Buahbatu, No.212 Bandung, Jawa Barat 


\subsubsection{Penataan Pentas}

Tata pentas dalam pengertian luas yaitu suasana seputar gerak laku di atas pentas dan seluruh elemen - elemen visual atau yang nampak oleh mata yang mengitari pemeran dalam pementasan. Tata pentas dalam pengertian teknik terbatas merupakan benda yang mencetak sebuah latar belakang fisik dan memberikan batas lingkungan gerak laku. Bersama mengacu terhadap definisi di atas bisa ditarik satu buah pengertian bahwa tata pentas merupakan seluruhnya latar belakang dan bendabenda yang ada di panggung guna menopang satu orang pemeran memainkan lakon.

Dari hasil pengertian tersebut, desain pentas pada sebuah pertunjukan tugas akhir karya seni ini sangat dibutuhkan. Karena sebagai aspek dalam segi visual, agar menunjang pada konsep yang penyaji usung. Panggung untuk pertunjukan tugas akhir kali ini yaitu panggung prosenium atau panggung pigura. Oleh karena itu, penyaji akan menggambarkan tata pentas panggung yang disesuaikan dengan artistik bertemakan cinta. Berikut desain pentas yang penyaji gambarkan. 


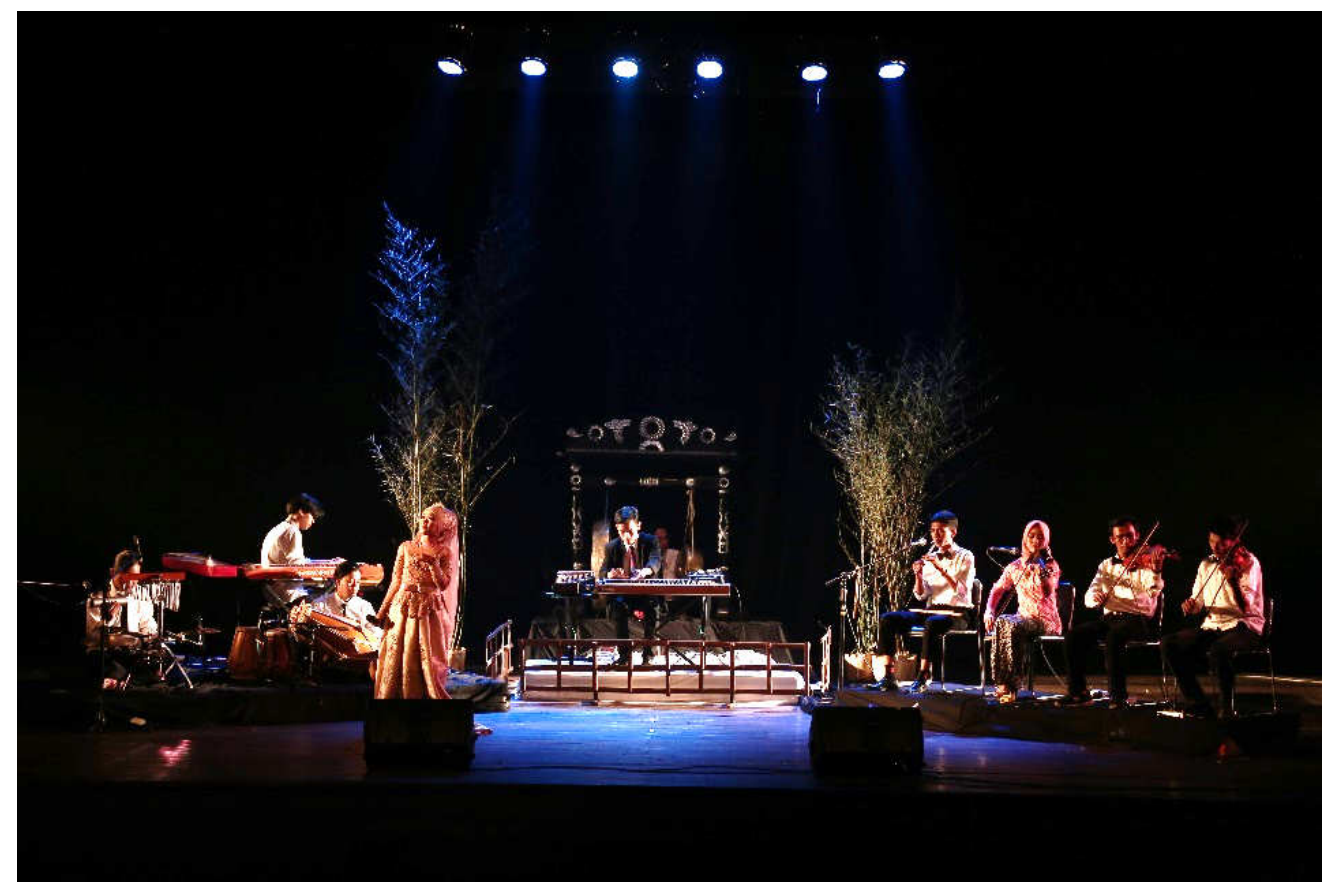

Gambar 1. Layout panggung TA Leungiteun

\subsubsection{Intsrumen Yang Digunakan}

* 3 buah Kacapi Siter untuk penyaji

* Kendang

* Suling

* Goong

* Perkusi

- Biola 1

- Biola 2

* Biola 3 


\subsubsection{Kostum}

Kostum adalah hal yang sangat penting untuk menyajikan sebuah pertujukan agar terlihat lebih menarik dan sesuai dengan alur cerita yang dibawakan. Kostum yang digunakan oleh pendukung vokal wanita menggunakan kabaya, untuk vokal pendukung pria menggunakan kameja putih, jas warna hitam dan dasi. Untuk pendukung pria menggunakan kostum kameja putih, dan penyaji sesbagai pria menggunakan kameja putih, dasi, dan jas warna hitam.

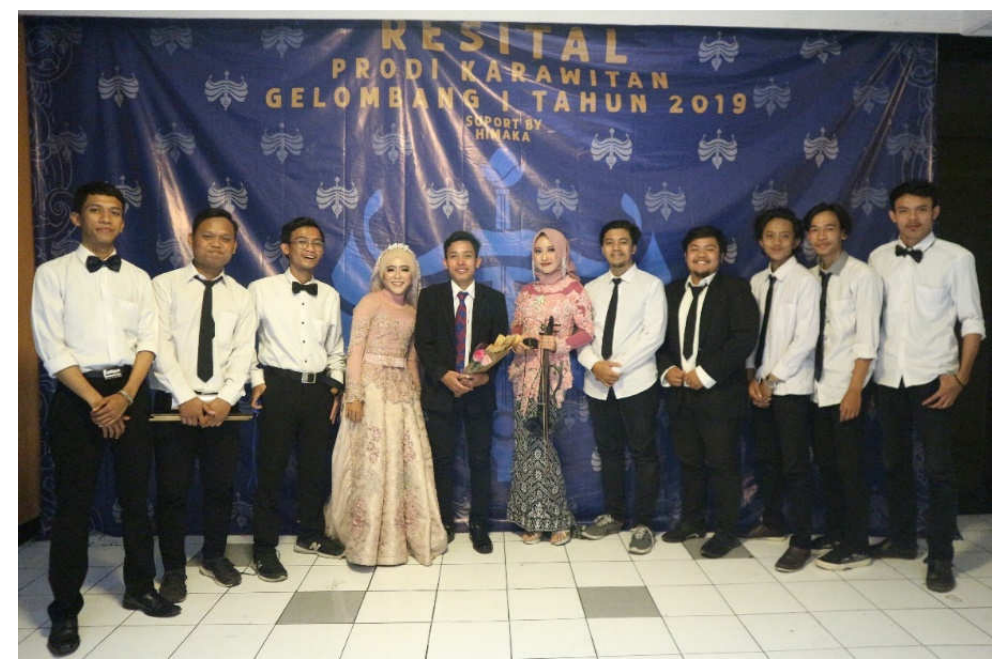

Gambar 2. kostum TA Leungiteun

\subsubsection{Pendukung}

Pendukung yang membantu dalam sajian ini sangat penting sehingga berjalannya sajian dalam tugas akhir ini. Para pendukung adalah mahasiswa ISBI Bandung jurusan karawitan 
Tabel 1

Penduku8ng TA Leungiteun

\begin{tabular}{|c|c|}
\hline 1. Nama & Tiarani Putri Irmayadi, S.pd. \\
\hline Umur & 25 \\
\hline Status & Pengajar/Guru SMK Bahagia Bandung \\
\hline Profesi & Vokal utama (Juru kawih) \\
\hline 2. Nama & Wiguna Supyanto \\
\hline Umur & 22 \\
\hline Status & Mahasiswa ISBI Bandung \\
\hline Propesi & Kendang \\
\hline 3. Nama & Geri Ilham Apriliam \\
\hline Umur & 22 \\
\hline Status & Mahasiswa ISBI Bandung \\
\hline Propesi & Suling \\
\hline 4. Nama & Alkha khoerul Krisnamukti \\
\hline Umur & 19 \\
\hline Status & Mahasiswa ISBI Bandung \\
\hline Propesi & Goong \\
\hline 5. Nama & Rizki Ferry Ramdani \\
\hline 6. Umur & 21 \\
\hline Status & Mahasiswa ISBI Bandung \\
\hline Propesi & Perkusi latin \\
\hline 7. Nama & Lutpi Budianto \\
\hline Umur & 20 \\
\hline Status & Alumni SMKN 10 Bandung \\
\hline Propesi & Kacapi Rincik \\
\hline
\end{tabular}




\begin{tabular}{|c|l|}
\hline 8. Nama & Frahma Ayudia Smarinda \\
Umur & 21 \\
Status & Mahasiswa ISBI Bandung \\
Propesi & Biola \\
\hline 9. Nama & Hikmat Maulana Yusuf \\
Umur & 21 \\
Status & Mahasiswa ISBI Bandung \\
Propesi & Biola \\
\hline 10. Nama & Rival \\
Umur & 22 \\
Status & Mahasiswa ISBI Bandung \\
Propesi & Biola \\
\hline 11. Nama & Yasa Pranata \\
Umur & 20 \\
Status & Mahasiswa ISBI Bandung \\
Propesi & Vokal utama (juru kawih) \\
\hline
\end{tabular}

\subsection{Konsep Garap}

Konsep garap yang dibawakan penyaji adalah garapan pembawaan kacapi kawih wanda anyar. Garapan ini penyaji membawakan konsep non konvensional yaitu menyajikan sajian kacapi kawih wanda anyar dengan mengaransmen gending, dan menyajikannya dengan konsep medley. 
Terdapat beberapa perubahan dalam memainkan kacapi kawih yang mungkin berbeda dari sebelumnya yaitu dalam waditra bubuka memakai kacapi dengan laras madenda 4=Tugu. Dilanjutkan dengan lagu lagu yang akan dibawakan terdiri dari laras mataram (3=Panelu), 4=Panelu. Dalam beberapa lagu tersebut terdapat waditra yang menjadi jembatan perpindahan laras.

Adapun materi lagu yang penyaji bawakan pada tugas akhir ini disusun berdasarkan panggunaan laras atau tangga nada yang ada pada kacapi sehingga menghasilkan melodi yang dibutuhkan oleh penyaji dimulai dengan materi lagu yang dikelompokan pada laras yang dibawakan.

\subsection{Bentuk Karya}

Materi lagu yang penyaji bawakan pada penyajian pertunjukan kacapi dalam kawih wanda anyar dengan judul "Leungiteun" ini disusun berdasarkan panggunaan laras atau tangga nada yang ada pada kacapi, sehingga menghasilkan melodi yang dibutuhkan oleh penyaji dimulai dengan bubuka dan dilanjutkan dengan materi lagu yang dikelompokan pada laras yang dibawakan. Oleh karena itu, secara khusus bahasan pada 
bentuk karya ini penyaji akan mengetengahkan deskripsi penyajian dan reportor lagu pada Tugas Akhir sebagai berikut:

\subsubsection{Reporotoar Lagu}

\section{Bubuka}

Bubuka merupakan sebuah komposisi musik atau gending hasil aransemen penyaji yang dibuat sebagai pembuka sajian, dan ditempatkan dibagian awal pertunjukan. Dalam komposisi musik bubuka, semua waditra yang digunakan dalam pertunjukan Lengiteun dimainkan bersama dengan menggunakan laras madenda 4=Tugu. Berikut ini adalah notasi komposisi gending bubuka:

\section{Notasi}

\section{BUBUKA}

Laras Madenda $4=\mathrm{T}$

\begin{tabular}{|c|c|c|c|c|c|c|c|c|c|}
\hline \multirow{5}{*}{ Kacapi: } & \multirow{3}{*}{$\begin{array}{l}\mathrm{KA} \\
\mathrm{KU}:\end{array}$} & . & . & . & . & . & . & . & \multirow{2}{*}{$\begin{array}{l}\text { NG } \\
5\end{array}$} \\
\hline & & . & . & . & . & . & . & . & \\
\hline & & . & . & . & . & . & . & . & 5 \\
\hline & & . & . & . & . & . & . & . & 3 \\
\hline & & . & . & . & . & . & . & . & 2 \\
\hline Violin + & acapi II & . & . & . & . & . & . & . & $\overline{54} \quad \overline{32}$ \\
\hline
\end{tabular}

\begin{tabular}{|c|c|c|c|c|c|c|c|c|c|}
\hline \multirow{5}{*}{ Kacapi: } & & . & $\mathrm{p}$ & . & - & . & $\mathrm{p}$ & . & \\
\hline & KA & . & . & . & . & . & . & . & $i_{1}$ \\
\hline & $\mathrm{KU}:$ & . & . & . & . & . & . & . & 5 \\
\hline & & . & . & . & . & . & . & . & 3 \\
\hline & & . & . & . & . & . & . & . & 1 \\
\hline \multicolumn{2}{|c|}{ Violin + Kacapi II } & $\overline{12} \overline{32}$ & $\overline{02} \overline{32}$ & $\overline{12} \overline{34}$ & $\overline{54} \overline{32}$ & $\overline{12} \overline{32}$ & $\overline{02} \overline{32}$ & $\overline{12} \overline{34}$ & $\overline{54} \overline{32}$ \\
\hline
\end{tabular}




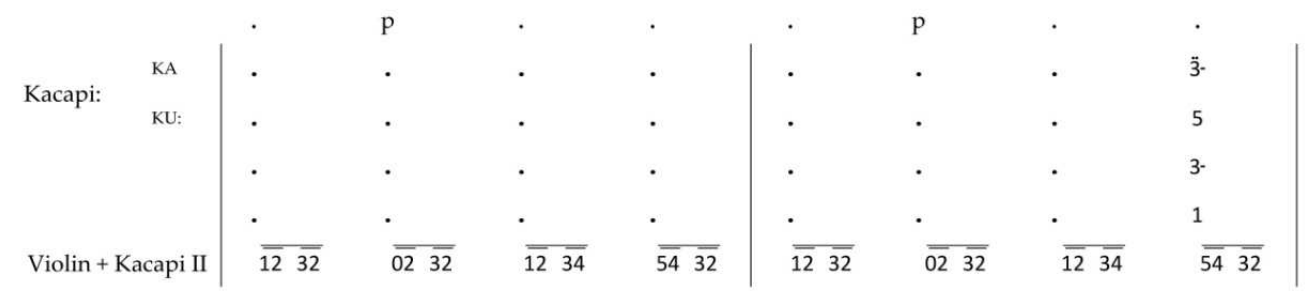

\begin{tabular}{|c|c|c|c|c|c|c|c|c|}
\hline \multirow{5}{*}{ Kacapi: } & . & $p$ & . & $\mathrm{p}$ & . & $\mathrm{p}$ & . & NG \\
\hline & . & . & . & 12 & . & . & . & 5 \\
\hline & . & . & . & 4 & . & . & . & 5 \\
\hline & . & . & . & 2 & . & . & . & 3 \\
\hline & . & . & . & 4. & . & . & . & 2 \\
\hline Violin + Kacapi II & $\overline{12} 34$ & $54 \quad 32$ & $\overline{12} 35$ & $43 \quad \overline{21}$ & 59121 & 2 & . & $54 \quad 32$ \\
\hline Violin & $\cdot$ & $\cdot$ & $\cdot$ & $\cdot$ & $\cdot$ & $\cdot$ & $\cdot$ & 5 \\
\hline Suling & . & . & . & . & . & . & . & 5 \\
\hline
\end{tabular}

\begin{tabular}{|c|c|c|c|c|c|c|c|c|}
\hline \multirow{5}{*}{ Kacapi: } & . & $\mathrm{p}$ & . & . & . & $\mathrm{p}$ & . & . \\
\hline & 5 & 5 & . & 5 & 5 & 5 & . & 11 \\
\hline & $\overline{505}$ & 5 & . & 555 & $\overline{50 \overline{5}}$ & 5 & . & 5 \\
\hline & $30 \overline{3}$ & 3 & . & 333 & $\overline{303}$ & 3 & . & 3 \\
\hline & 202 & 2 & . & 222 & $20 \overline{2}$ & 2 & . & 1 \\
\hline Violin + Kacapi II & $12 \quad 32$ & $\overline{02 \quad 32}$ & $12 \quad \overline{34}$ & $54 \quad 32$ & 1232 & $02 \quad 32$ & $12 \quad 34$ & $54 \quad 32$ \\
\hline Violin & 505 & 5 & . & 555 & 505 & 5 & 502 & 3 \\
\hline Suling & 505 & 5 & . & 555 & $5 \quad 05$ & 5 & $5 \quad \overline{02}$ & 1 \\
\hline
\end{tabular}

\begin{tabular}{|c|c|c|c|c|c|c|c|c|c|}
\hline \multirow{5}{*}{ Kacapi: } & i & $\mathrm{p}$ & . & $i$ & is & & $\mathrm{p}$ & is & . \\
\hline & & & & & & & & & \\
\hline & 505 & 5 & - & 555 & 5 & 05 & 5 & - & 5 \\
\hline & $30 \overline{3}$ & 3 & . & 333 & 3 & 03 & 3 & . & 3- \\
\hline & 101 & 1 & . & 222 & 2 & 02 & 1 & . & 1 \\
\hline Violin + Kacapi II & 1232 & 0232 & 1234 & 5432 & 12 & 32 & 0232 & 1234 & 5432 \\
\hline Vuolin & - & . & . & . & . & & . & . & 3. \\
\hline Suling & . & . & . & . & . & & . & . & 5 \\
\hline
\end{tabular}




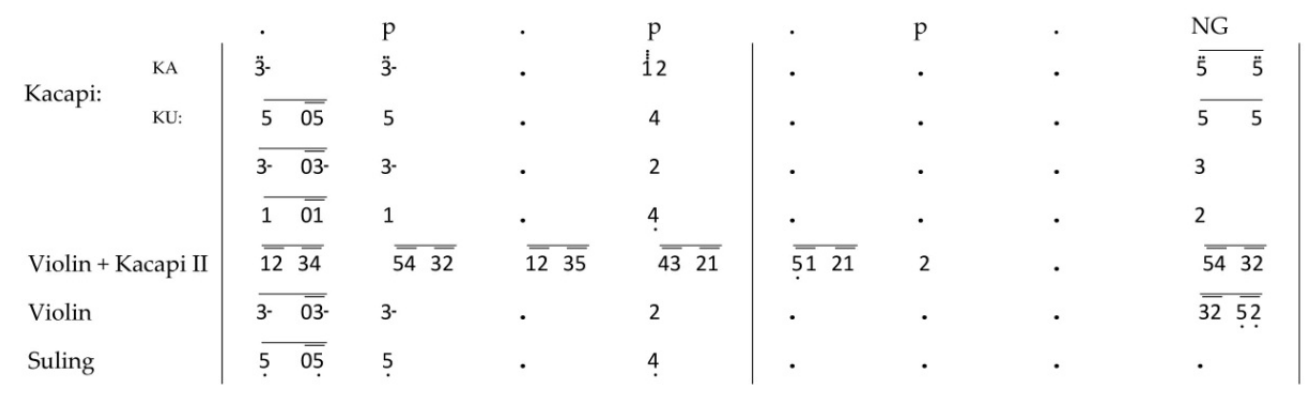

\begin{tabular}{|c|c|c|c|c|c|c|c|c|c|c|c|c|}
\hline \multirow{5}{*}{ Kacapi: } & \multirow{2}{*}{\multicolumn{2}{|c|}{$0 \overline{05} \overline{05}$}} & $\mathrm{p}$ & . & \multicolumn{2}{|l|}{$\cdot$} & $=$ & \multicolumn{2}{|c|}{$\mathrm{p}$} & \multicolumn{2}{|l|}{. } & $\dot{1} \square$ \\
\hline & & & . & $\cdot$ & $\overline{5}$ & $\overline{5}$ & $\overline{05} 0 \overline{5}$ & . & & . & & $\overline{11} \quad 11$ \\
\hline & 0 & 5 & 0 & 0 & 0 & 5 & 0 & 0 & $\overline{5}$ & 0 & 5 & 5 \\
\hline & 3 & & 3 & 3 & 3 & & 3 & 3 & & 3 & & 3 \\
\hline & 2 & & 2 & 2 & 2 & & 2 & 2 & & 2 & & 1 \\
\hline Violin + Kacapi II & & $\overline{32}$ & $\overline{02} \overline{32}$ & $\overline{12} \overline{34}$ & & $\overline{32}$ & $\overline{12} \overline{32}$ & $\overline{02} \quad \overline{3}$ & 32 & & 34 & $\overline{54} \overline{32}$ \\
\hline Violin & 04 & $\overline{03}$ & . & . & . & & . & . & & . & & $32 \overline{52}$ \\
\hline Suling & . & & $\overline{32} \overline{52}$ & $\overline{04} \overline{03}$ & . & & . & . & & . & & . \\
\hline
\end{tabular}

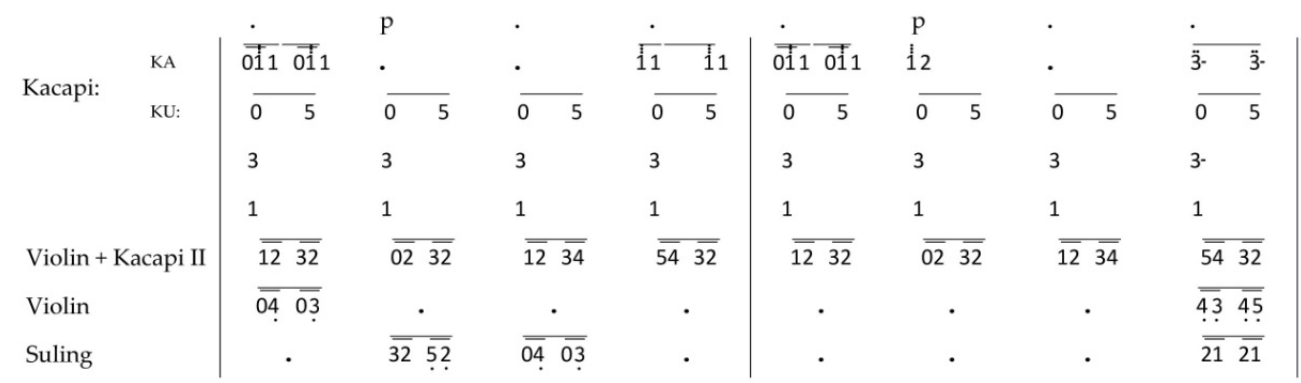

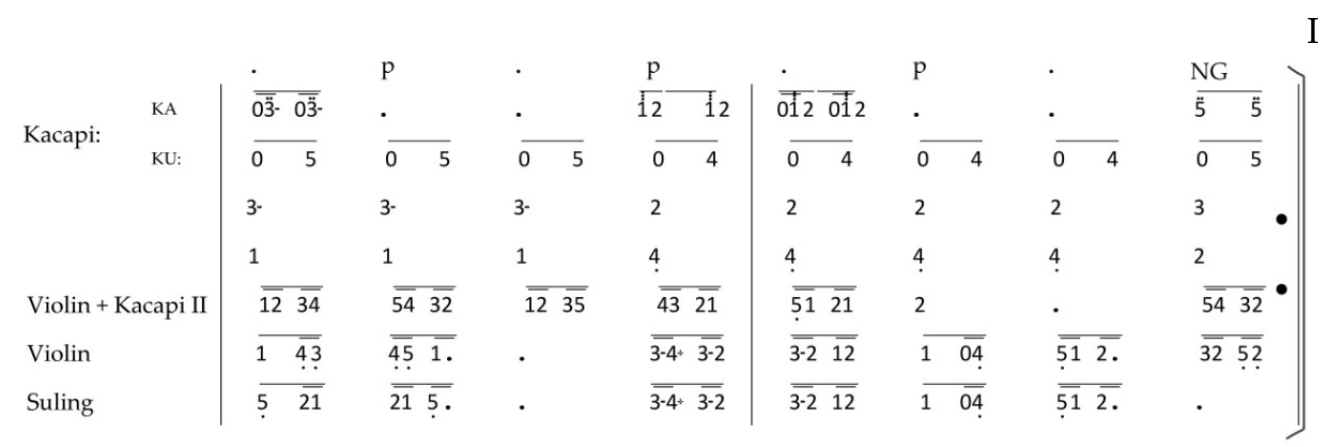




\begin{tabular}{|c|c|c|c|c|c|c|c|c|c|}
\hline \multirow{3}{*}{ Kacapi: } & \multirow[b]{2}{*}{$\mathrm{KA}$} & \multicolumn{2}{|l|}{. } & \multicolumn{2}{|l|}{$\mathrm{p}$} & \multicolumn{2}{|c|}{$\cdot$} & \multicolumn{2}{|c|}{ NG } \\
\hline & & \multicolumn{2}{|c|}{$\overline{012} \overline{0 i 2}$} & \multicolumn{2}{|c|}{$\cdot$} & \multicolumn{2}{|l|}{. } & $\overline{5}$ & $\overline{5}$ \\
\hline & \multirow[t]{3}{*}{$\mathrm{KU}$; } & 0 & 4 & 0 & 4 & 0 & 4 & 0 & 5 \\
\hline & & 2 & & 2 & & 2 & & 3 & \\
\hline & & 4 & & 4 & & 4 & & 2 & \\
\hline \multicolumn{2}{|c|}{ Violin + Kacapi II } & $5 \underline{1}$ & $\overline{21}$ & 2 & & - & & 54 & 32 \\
\hline Violin & & $3-2$ & $\overline{12}$ & 1 & 04 & $\overline{51}$ & 2. & $\overline{33}$ & $\overline{34}$ \\
\hline Suling & & $3-2$ & 12 & 1 & 04 & & 2. & 33 & 34 \\
\hline
\end{tabular}

\begin{tabular}{|c|c|c|c|c|c|c|c|c|c|c|c|c|c|c|}
\hline \multirow{3}{*}{ Kacapi: } & . & \multicolumn{2}{|l|}{$\mathrm{p}$} & \multicolumn{2}{|l|}{ · } & \multicolumn{2}{|l|}{. } & \multicolumn{2}{|l|}{. } & \multicolumn{2}{|l|}{$\mathrm{p}$} & \multicolumn{2}{|c|}{. } & . \\
\hline & $\overline{0 \overline{05}} \overline{0 \overline{5}}$ & . & & - & & 5 & $\overline{5}$ & & $\overline{05}$ & - & & - & & $3-$ \\
\hline & 5 & 0 & 5 & 0 & 5 & 0 & 5 & 0 & 5 & 0 & 5 & 0 & 5 & 0 \\
\hline & 3 & 3 & & 3 & & 3 & & 3 & & 3 & & 3 & & 3 \\
\hline & 2 & 2 & & 2 & & 2 & & 2 & & 2 & & 2 & & 1 \\
\hline Violin Kacapi II & $12 \overline{32}$ & $\overline{02}$ & 32 & $\overline{12}$ & 34 & $\overline{54}$ & 32 & 12 & 32 & 02 & 32 & 12 & 34 & \\
\hline Violin & $0 \quad \overline{54}$ & 5 & . & . & & 33 & 34 & 0 & 54 & 5 & . & . & & $\overline{3-4+3-2}$ \\
\hline Suling & $05 \overline{4}$ & 5 & . & . & & 333 & & $05 \overline{4}$ & & 52 & . & . & & \\
\hline & & & & & & & & Ran & npa & ncik, & Su & Violin & & \\
\hline
\end{tabular}

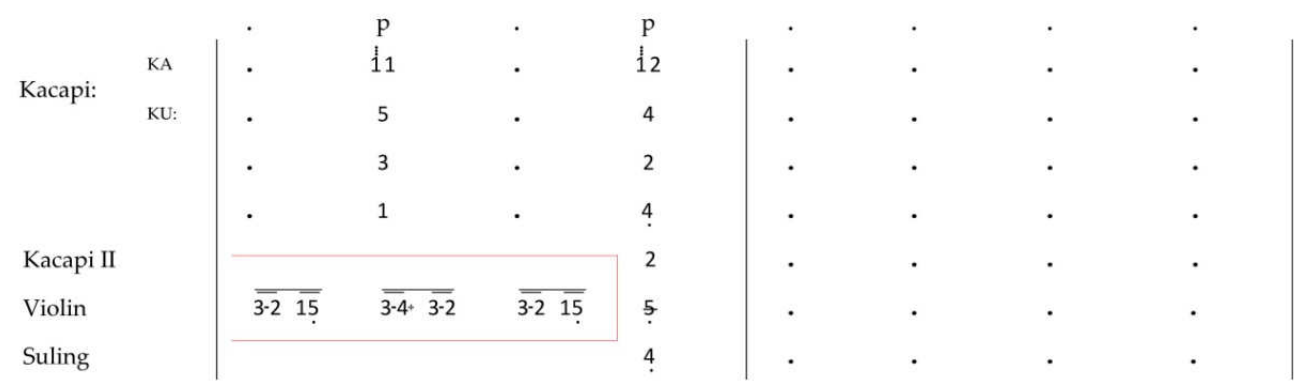

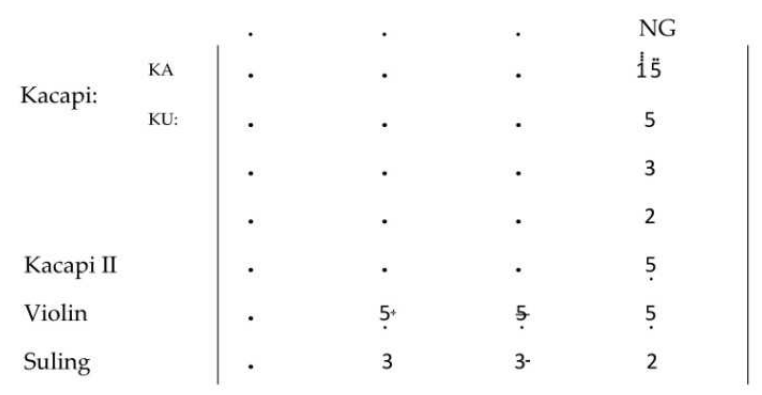




\section{Dua Saati}

Dua Saati diciptakan oleh Nano S. pertama dibuat menggunakan iringan gamelan degung kreasi dengan menggunakan laras madenda 4=Tugu. dalam kontek sajian pertunjukan Lengiteun lagu tersebut diiringi menggunakan waditra utama kacapi, dilengkapi dengan waditra kendang, suling, goong, biola, dan perkusi latin. Aransemen kacapi dalam lagu Dua Saati menggunakan teknik tabuhan sebagai berikut:

1. Teknik sintreuk dan toel pada bagian intro,

2. Teknik diranggeum pada bagian iringan lagu dua goongan pertama,

3. Teknik dijambret pada iringan lagu goongan 3 dan 4 .

Berikut ini adalah notasi komposisi Dua Saati:

\section{DUA SAATI}

Intro: Embat Sawilet

Laras Madenda $4=\mathrm{T}$

\begin{tabular}{|c|c|c|c|c|c|c|c|c|c|c|c|c|}
\hline \multirow{3}{*}{ Kacapi : } & & . & r. & . & \multicolumn{2}{|c|}{ NG } & . & \multicolumn{2}{|l|}{ p } & . & \multicolumn{2}{|l|}{. } \\
\hline & KA & . & . & i & $\dot{3}$ & & i & $\dot{5}$ & & $\dot{4}$ & $\dot{3}$ & \\
\hline & $\mathrm{KU}:$ & - & . & 2 & & 2 & $\overline{34} \overline{34}$ & 5 & $\dot{i}$ & $\overline{5 i} \overline{54}$ & 3 & \\
\hline Kacapi II & $\mathrm{KA}:$ & . & . & . & 13. & & . & . & & . & 13. & \\
\hline & KU & . & . & . & 1 & 1 & 11 & 1 & 1 & $\overline{11}$ & $\overline{1}$ & 1 \\
\hline & & . & . & . & 5 & & 5 & 5 & & 5 & 5 & \\
\hline Violin & & . & . & . & . & & . & . & & . & 0 & $\bar{i}$ \\
\hline Suling & & . & . & . & . & & . & . & & . & 0 & $\overline{\mathrm{i}}$ \\
\hline
\end{tabular}




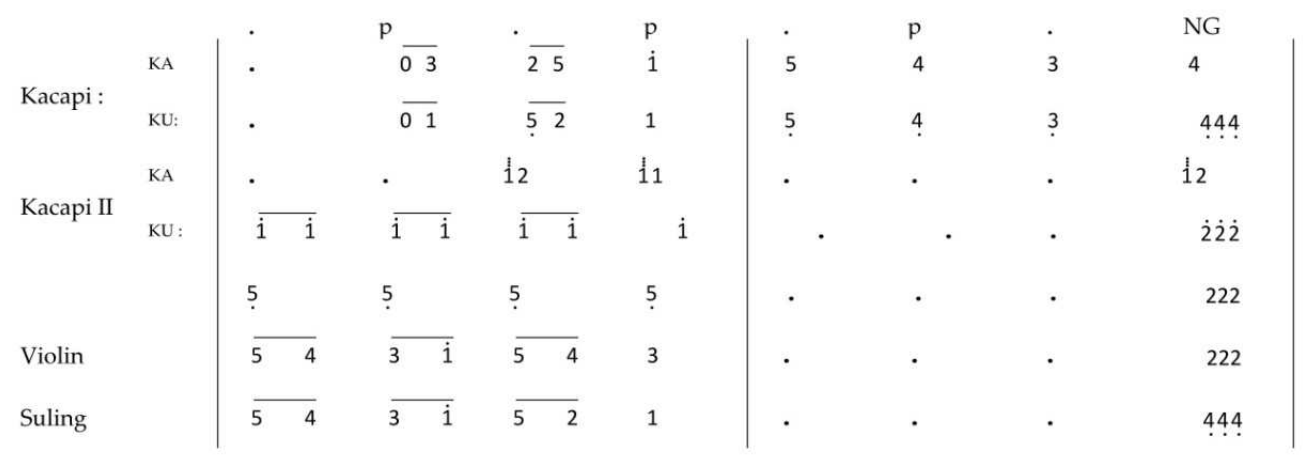

\begin{tabular}{|c|c|c|c|c|c|c|c|c|c|}
\hline \multirow[b]{3}{*}{ Kacapi : } & & . & $p$ & . & . & . & $\mathrm{p}$ & . & . \\
\hline & KA & 4 & 4 & 4 & 3 & 4 & 5 & i & $\dot{i}$ \\
\hline & $\mathrm{KU}:$ & 4.4 & 444 & 454 & 3 & 4 & 5 & 1 & 2 \\
\hline \multirow{3}{*}{ Kacapi II } & $\mathrm{KA}$ & 12 & 12 & 12 & 11 & . & . & . & 5 \\
\hline & $\mathrm{KU}$ : & $\dot{2}$ & $\dot{2}$ & $\dot{2}$ & $i$ & . & . & . & 3 \\
\hline & & 2 & 2 & 2 & 1 & . & . & - & 2 \\
\hline Violin & & 222 & 222 & $23-2$ & 1 & . & . & . & 5 \\
\hline Suling & & 444 & 444 & 454 & 5 & . & . & - & 5 \\
\hline
\end{tabular}

\begin{tabular}{|c|c|c|c|c|c|c|c|c|c|}
\hline \multirow{3}{*}{ Kacapi : } & & $\cdot$ & p & . & $p$ & . & $p$ & & NG \\
\hline & $\mathrm{KA}$ & i & 5 & 2 & $\overline{354}$ & $\overline{05}$ & $\ddot{\text { iz }}$ & $\overline{3 \dot{3}}$ & $\dot{5}$ \\
\hline & $\mathrm{KU}:$ & 1 & 5 & 5 & 1 & 33 & $\overline{1212}$ & $\overline{34}$ & 5 \\
\hline \multirow{3}{*}{ Kacapi II } & $\mathrm{KA}$ & . & . & 12 & 11 & . & . & . & 5 \\
\hline & $\mathrm{KU}$ : & . & . & . & 5 & . & . & . & 3 \\
\hline & & . & . & . & 3 & . & . & . & 2 \\
\hline Violin & & 4 & 3 & 5 & 3 & . & . & . & $\overline{54} \quad \overline{32}$ \\
\hline Suling & & 4 & 3 & . & . & - & 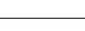 & 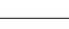 & 5 \\
\hline
\end{tabular}

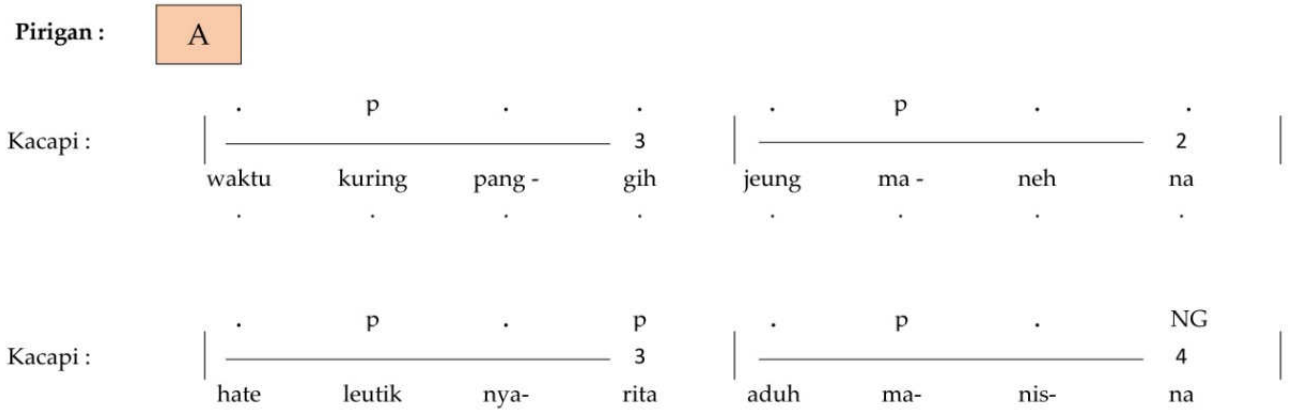




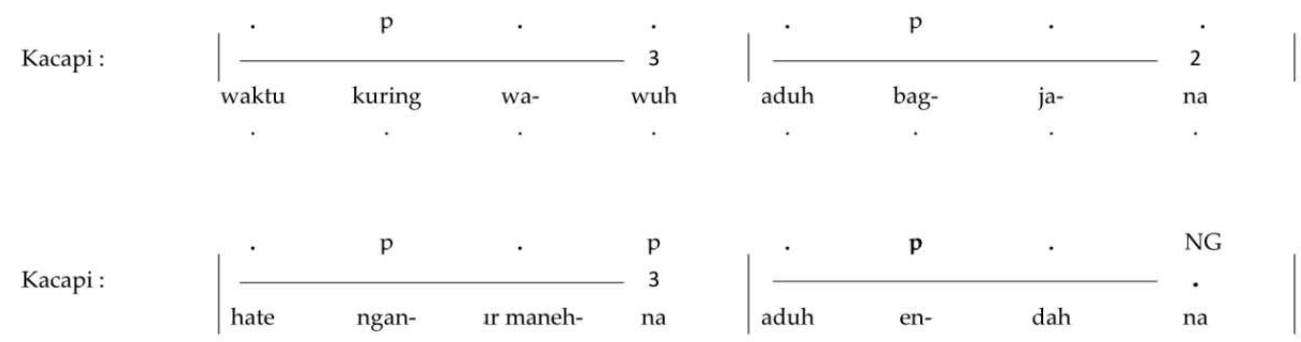

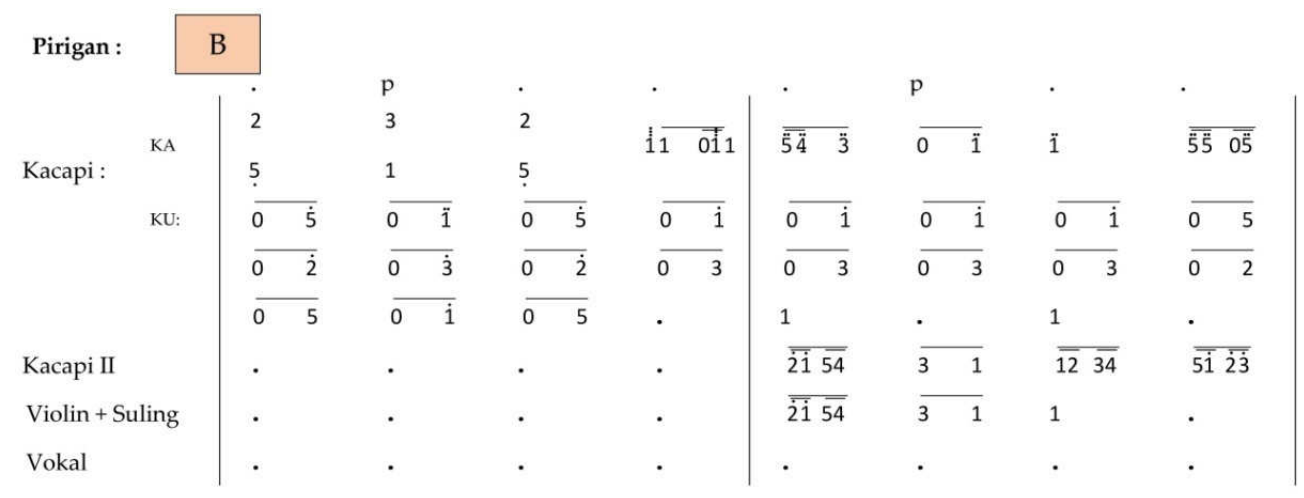

\begin{tabular}{|c|c|c|c|c|c|c|c|c|c|c|c|c|}
\hline \multirow{5}{*}{ Kacapi : } & $K A$ & . & $\mathrm{p}$ & . & \multicolumn{2}{|l|}{$p$} & \multicolumn{2}{|l|}{$\mathrm{p}$} & \multicolumn{2}{|l|}{. } & \multicolumn{2}{|c|}{ NG } \\
\hline & KA & $\begin{array}{ll}432 \\
\end{array}$ & 0323 & 4 & $\begin{array}{ll}11 & 011\end{array}$ & $\begin{array}{l}54 \quad 3 \\
\end{array}$ & 12 & 12 & 11 & 5 & & \\
\hline & $\mathrm{KU}:$ & $0 \quad 5$ & 0 & 0 & $\overline{0 i}$ & $\overline{0 i}$ & 0 & $\bar{i}$ & 0 & $\dot{\mathrm{i}}$ & 0 & 4 \\
\hline & & 0 & 0 & 0 & $\sqrt{3}$ & 0 & 0 & 3 & 0 & 3 & 0 & 2 \\
\hline & & 5 & . & 5 & . & 1 & . & & 1 & & . & \\
\hline Kacapi II & & $\overline{\overline{2 i 54}}$ & $\overline{31}$ & $\overline{1234}$ & $\overline{5123}$ & $\overline{2 \overline{i 54}}$ & & & & $\overline{53}$ & 4 & \\
\hline Violin & & $\overline{2 \overline{1}} \overline{54}$ & 3 & 1 & . & $\overline{21} \overline{54}$ & 3 & $\sqrt{4}$ & 5 & $\dot{\mathrm{i}}$ & $\dot{2}$ & \\
\hline Suling & & $\overline{21 \overline{54}}$ & 3 & 1 & . & $\overline{21 \overline{54}}$ & 3 & $\overline{4}$ & 5 & 3 & 4 & \\
\hline Vokal & & . & . & . & . & . & & & . & & . & \\
\hline
\end{tabular}

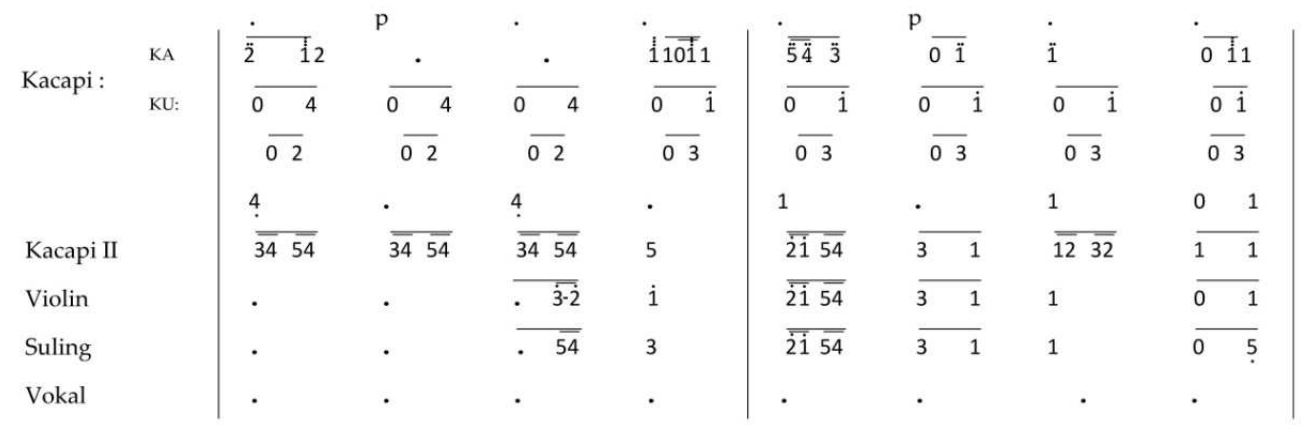




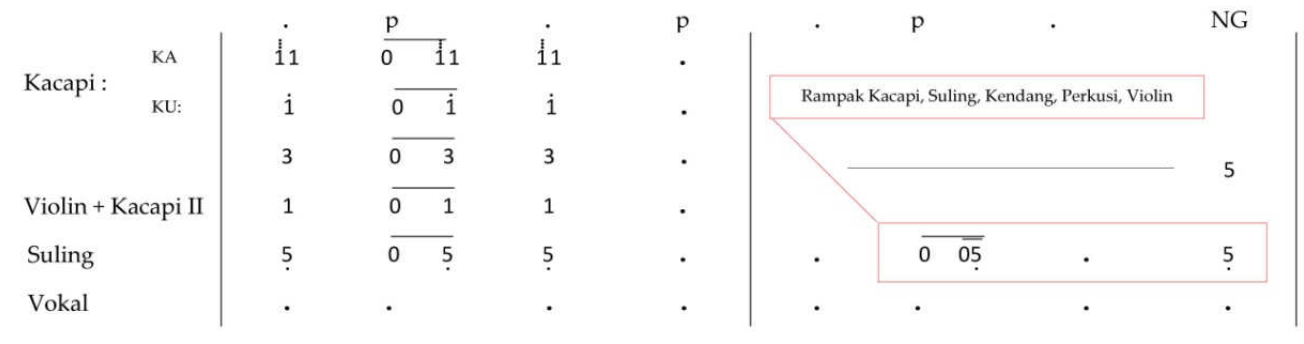

Kembali Pirigan : $\mathrm{A} \Rightarrow \mathrm{B}$ lu kembali ke Intro.

Gending Peralihan Embat : Triul

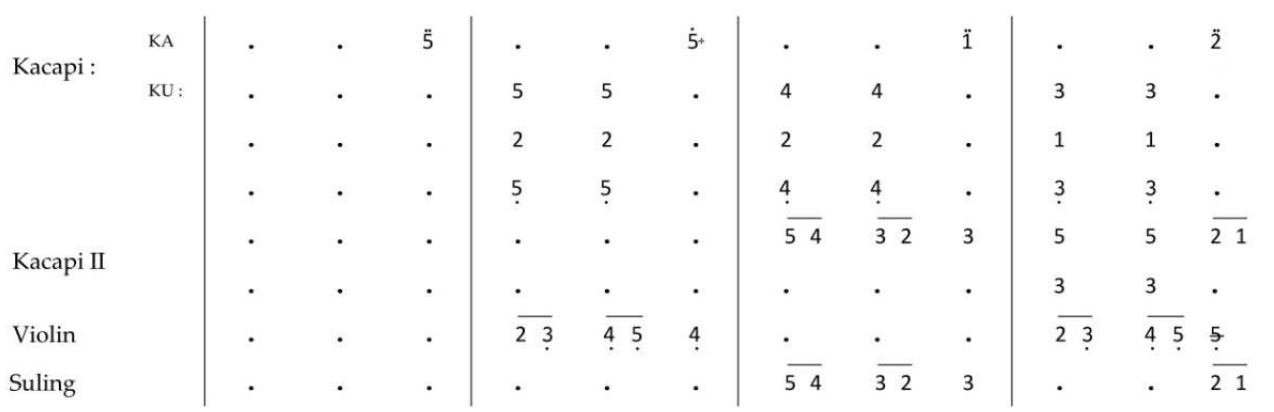

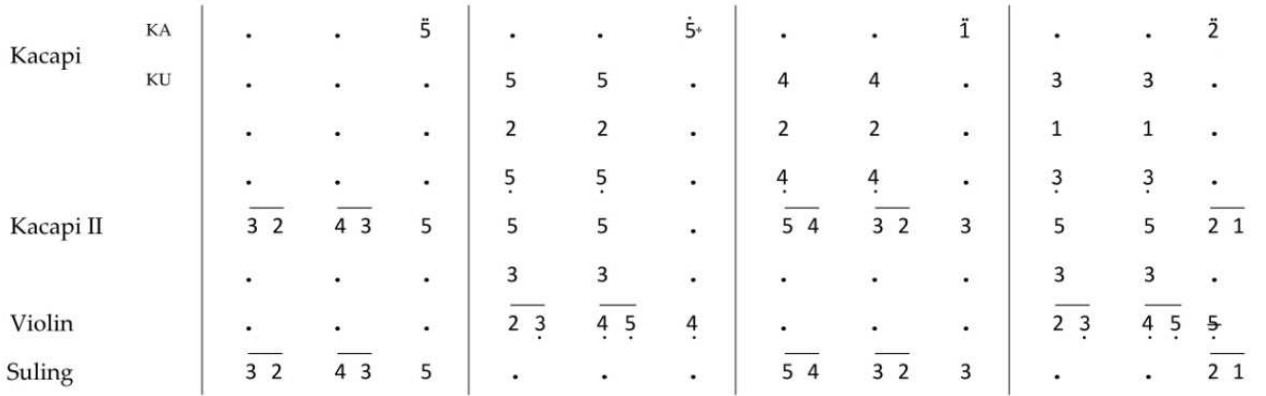

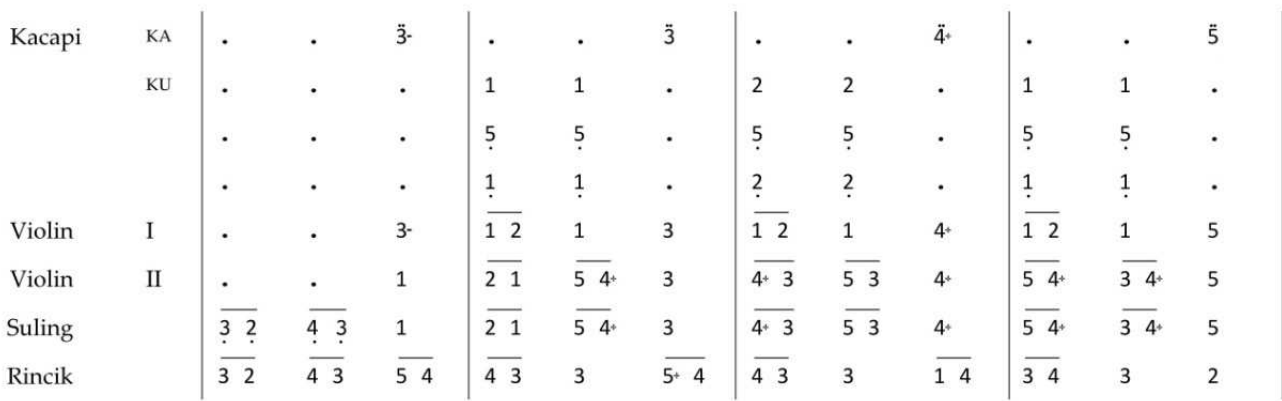




\begin{tabular}{|c|c|c|c|c|c|c|c|c|c|c|c|c|c|}
\hline \multirow[t]{4}{*}{ Kacapi } & KA & . & . & 5 & . & . & 11 & . & . & 12 & . & . & $\ddot{5}$ \\
\hline & $\mathrm{KU}$ & $\cdot$ & . & . & 1 & 1 & . & 2 & 2 & . & 1 & 1 & . \\
\hline & & . & . & . & 5 & 5 & . & 5 & 5 & . & 5 & 5 & . \\
\hline & & . & . & . & 1. & 1 & . & $?$ & $?$ & . & 1 & 1 & . \\
\hline Violin & I & . & . & $3-$ & $\overline{12}$ & 1 & 3 & $\overline{12}$ & 1 & $4^{+}$ & $\overline{12}$ & 1 & 5 \\
\hline Violin & II & 4 & 3 & 3. & $\overline{03}$ & $\overline{45}$ & 3 & $\overline{03}$ & $\overline{45}$ & $\overline{34}$ & $\overline{55}$ & $\overline{54}$ & 45 \\
\hline Suling & & 4 & 3 & $3-$ & $\overline{03}$ & $\overline{45}$ & 3 & $\overline{03}$ & $\overline{45}$ & $\overline{34}$ & $\overline{55}$ & $\overline{54}$ & 45 \\
\hline Rincik & & 3 & 4 & 5 & $\overline{43}$ & 3 & $\overline{14}$ & $\overline{43}$ & 3 & $\dot{2}$ & 3 & 4 & 5 \\
\hline
\end{tabular}

\section{Sulaya Jangji}

Sulaya jangji diciptakan oleh Mang Koko. Pertama dibuat menggunakan iringan kacapi dengan menggunakan laras madenda 4=Tugu. Dalam kontek sajian pertunjukan Lengiteun, lagu tersebut diiringi menggunakan waditra utama kacapi, dilangkapi dengan waditra kendang, suling, goong, biola, dan perkusi latin. Aransemen kacapi dalam lagu Sulaya jangi menggunakan teknik tabuhan sebagai berikut:

1. Teknik sintreuk dan toel pada bagian intro,

2. Teknik diranggeum pada bagian iringan lagu dua goongan Terakhir.

\section{SULAYA JANGJI}

Intro: Embat Sawilet

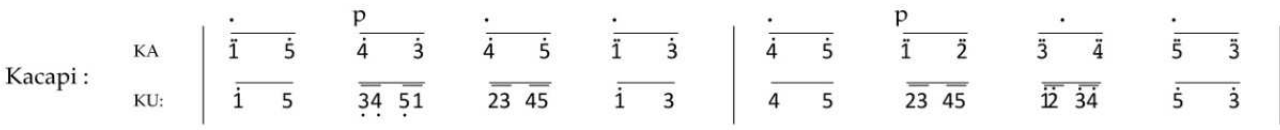

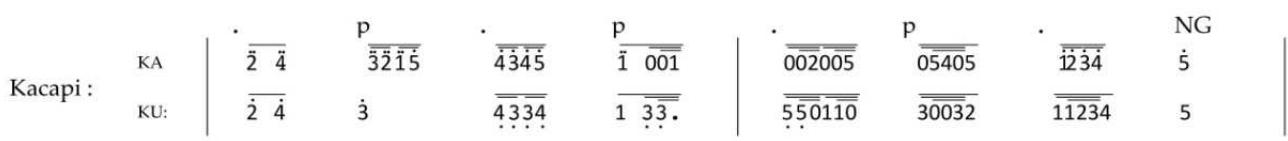

Pirigan : Embat Sawilet Anca

Laras Madenda $4=\mathrm{T}$ 


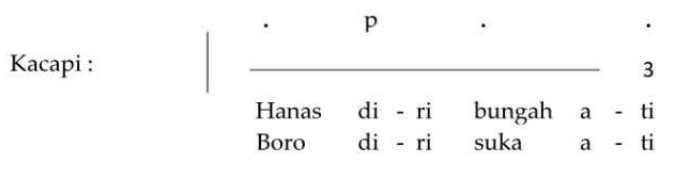

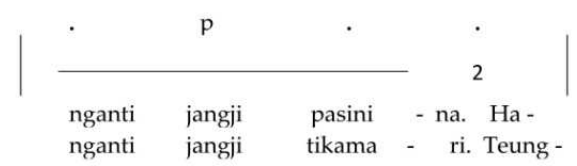

Kacapi :
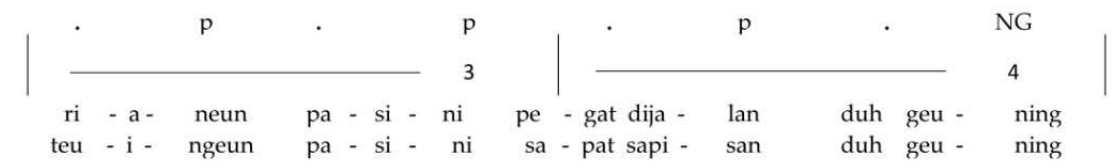

Kacapi :
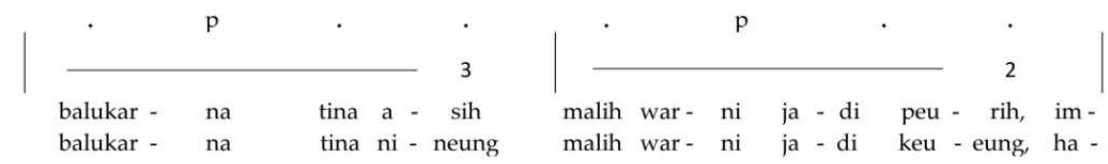

Kacapi :
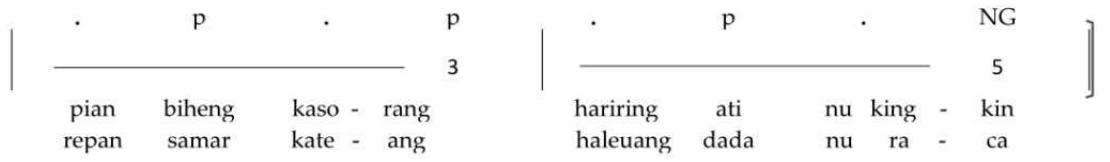

Kacapi :
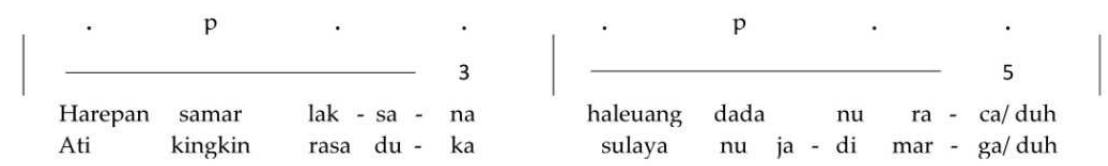

Kacapi :
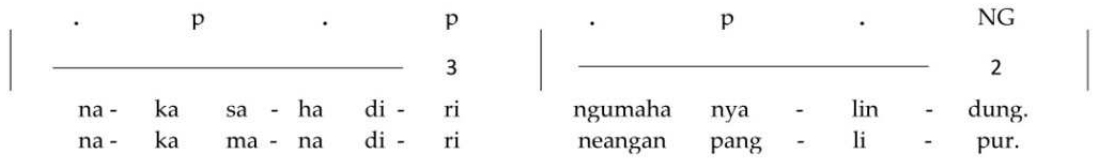

Kacapi :
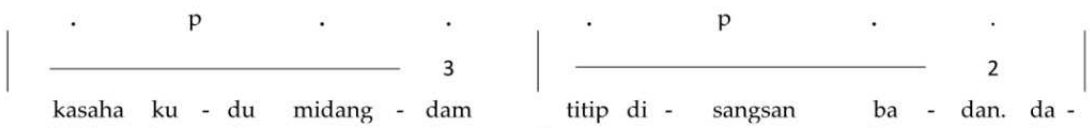
nitipkeun ba - dan sa - ku - jur kamana ngun - der pang - li - pur. da -

Kacapi :

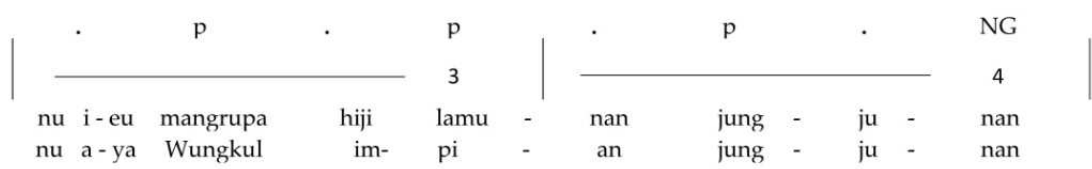


Kacapi :
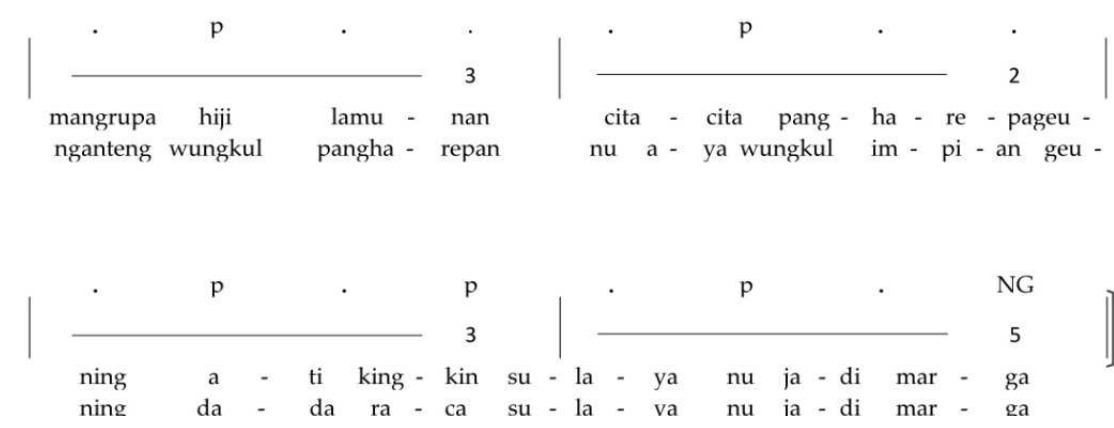

Gending Peralihan lagu : Laras Madenda $4=\mathrm{T}$

\begin{tabular}{|c|c|c|c|c|c|c|c|c|c|c|c|c|}
\hline \multirow{2}{*}{ Kacapi : } & $\mathrm{KA}$ & $\cdot$ & $\cdot$ & $\cdot$ & & 13 & - & & $\ddot{3}$ & . & & $\ddot{4}$ \\
\hline & KU: & . & . & . & & $\overline{05} \overline{43}$ & $\overline{21}$ & 5 & $\overline{03} \quad \overline{21}$ & $\overline{54}$ & 3 & $\overline{04} \overline{32}$ \\
\hline Kacapi II & & . & . & - & & 5 & . & & 3 & . & & 4 \\
\hline Violin & & . & . & 3- & 2 & 1 & . & & 2 & . & & $3-$ \\
\hline Suling & & . & . & . & & 5 & . & & $5+$ & . & & 1 \\
\hline
\end{tabular}

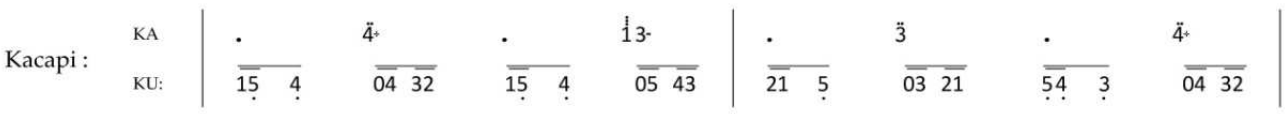

\begin{tabular}{|c|c|c|c|c|c|c|c|c|}
\hline Kacapi II & . & $\overline{34} \overline{51}$ & $21 \quad \overline{34}$ & 5 & . & 3 & . & 4 \\
\hline Violin & $\cdot$ & . & 3- 2 & 1 & . & 2 & . & 3- \\
\hline Suling & . & . & . & 5 & . & 5 & . & 1 \\
\hline
\end{tabular}

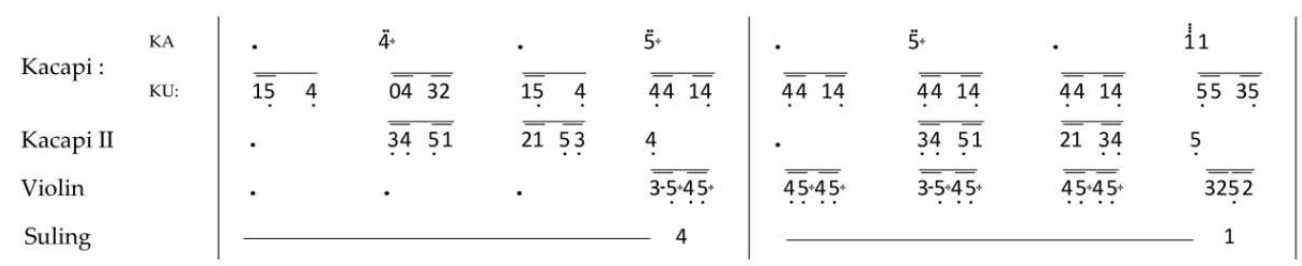

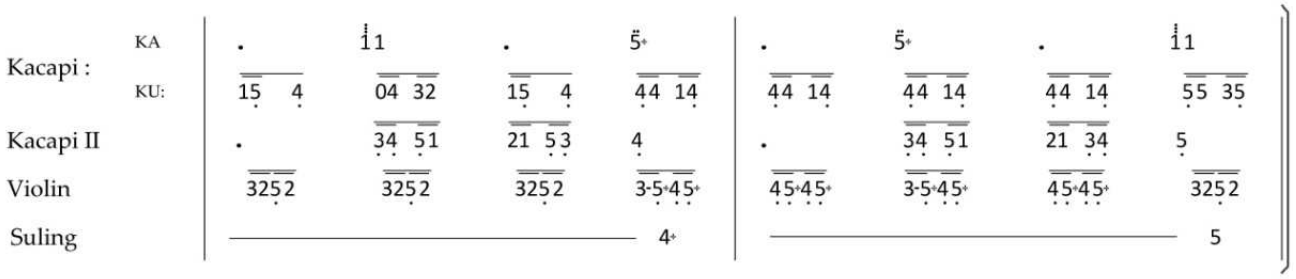




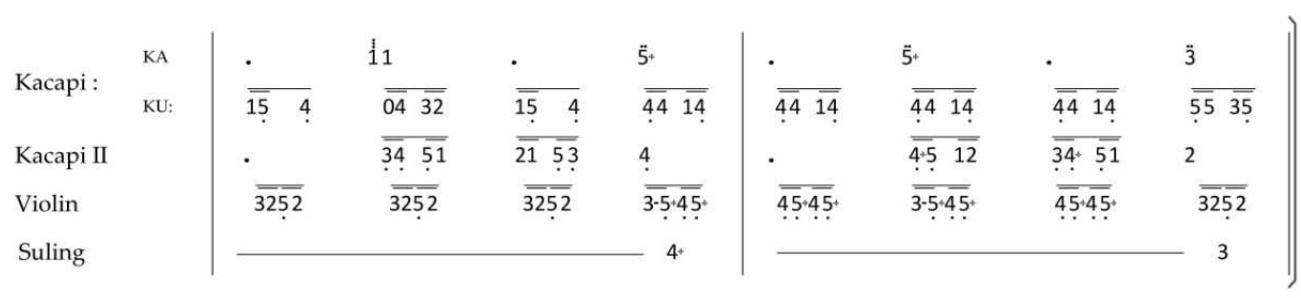

\begin{tabular}{|c|c|c|c|c|c|c|c|c|}
\hline & & cap & & & & & & \\
\hline & . & . & . & . & . & . & . & NG \\
\hline Kacapi : & . & . & . & $\overline{34} \quad \overline{51}$ & $\overline{21} \overline{51}$ & $4 \overline{45}$ & $\overline{31} \overline{23}$ & 4 \\
\hline
\end{tabular}

\section{Memang Sesah}

Memang Sesah diciptakan oleh Nano S. Penyaji mengambil dari rekaman Mp3 yang dinyanyikan oleh Rita Tila, kemudian diaransemen kembali dalam gending pada melodi kacapi seperti adanya tambahan melodi biola dan suling. Lagu Memang Sesah menggunakan laras degung 1=Panelu. dalam konteks sajian pertunjukan Lengiteun, lagu tersebut diiringi menggunakan waditra utama kacapi, dilangkapi waditra kendang, suling, goong, biola, dan perkusi latin. Aransemen kacapi dalam lagu Memang Sesah menggunakan teknik tabuhan sebagai berikut:

1. Teknik Sintreuk dan Toel pada bagian intro,

2. Teknik diranggeum pada bagian iringan lagu dua goongan terakhir.

Berikut ini adalah notasi komposisi gending Memang Sesah: 


\section{MEMANG SESAH}

Intro:

Laras Madenda $3=\mathrm{T}$

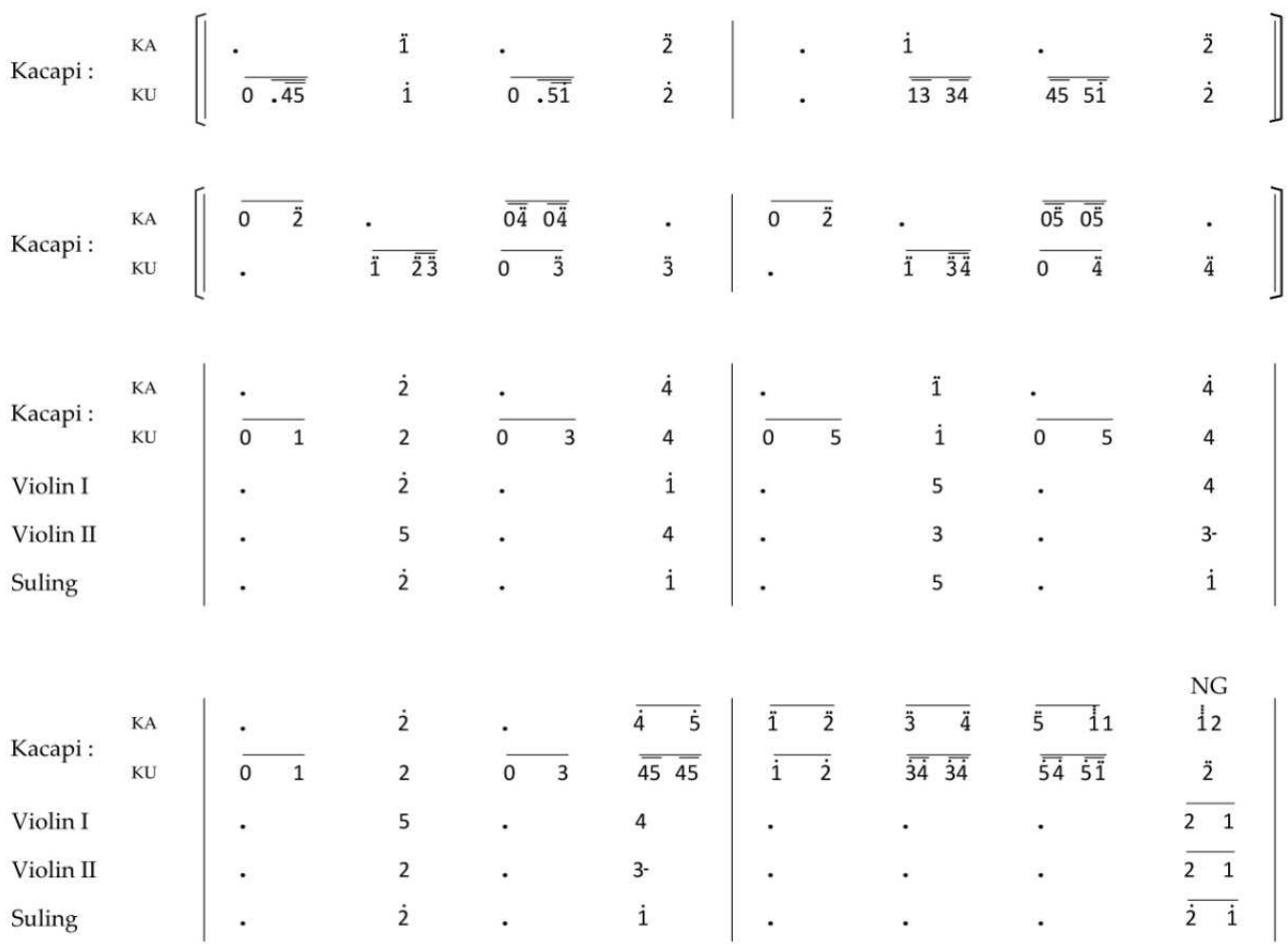

Pirigan : Sawilet Anca

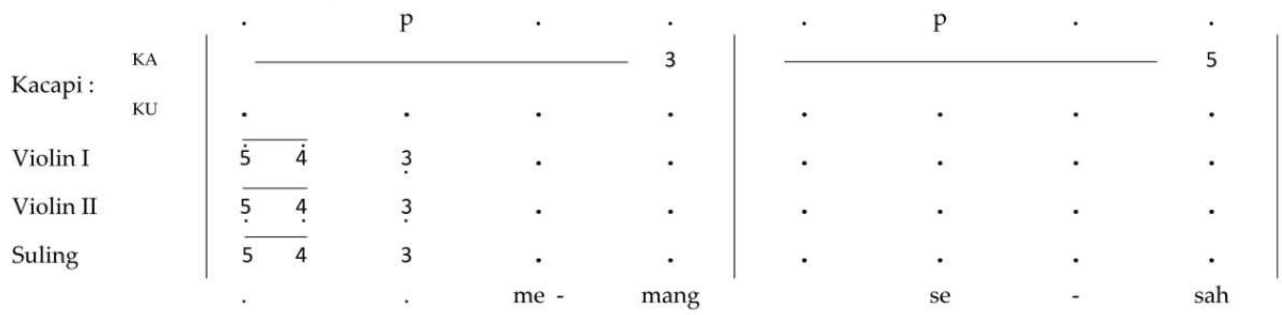

Kacapi :

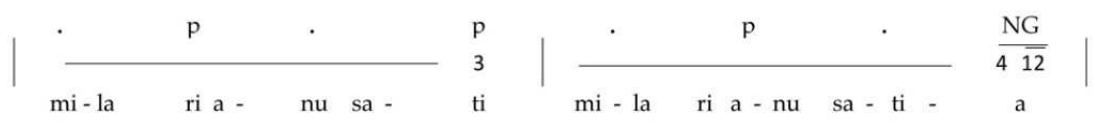

Kacapi :

Violin I

Violin II

Suling

\begin{tabular}{|c|c|c|c|c|c|c|c|}
\hline . & $p$ & . & . & $\cdot$ & $\mathrm{p}$ & . & . \\
\hline$\overline{34} \overline{51}$ & $\overline{23} \overline{42}$ & 3 & . & . & 5 & 3 & 4 \\
\hline & 4 & & - & - & 5 & 3 & 1 \\
\hline & RW & & - & . & 5 & 3 & 3- \\
\hline . & . & me & mang & . & se & - & sah \\
\hline
\end{tabular}




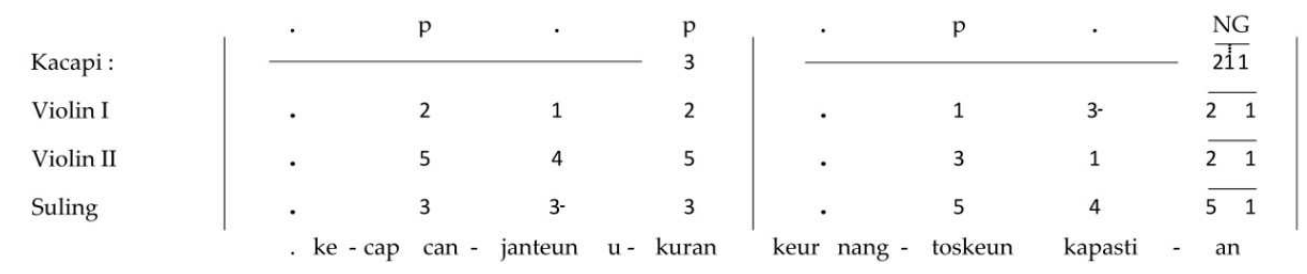

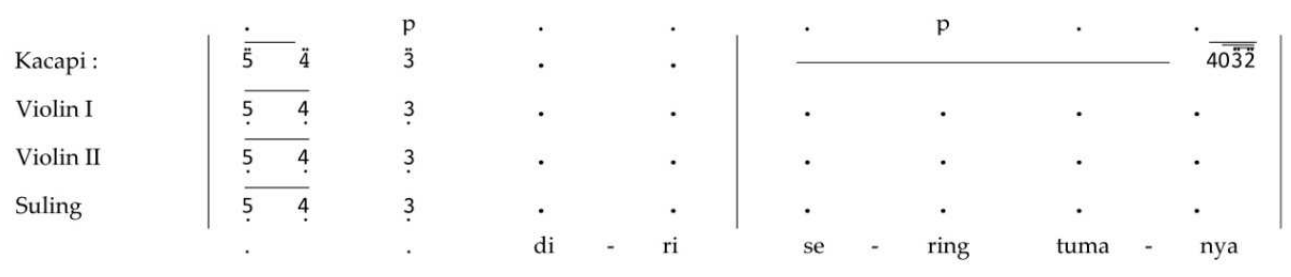

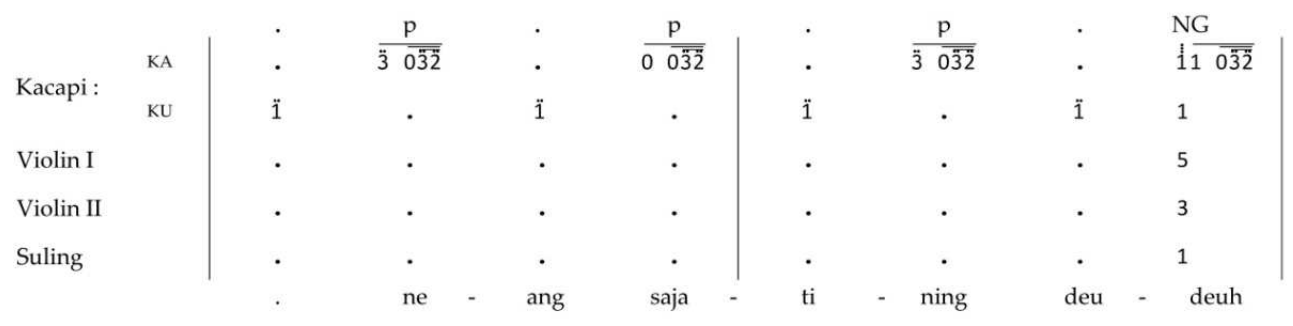

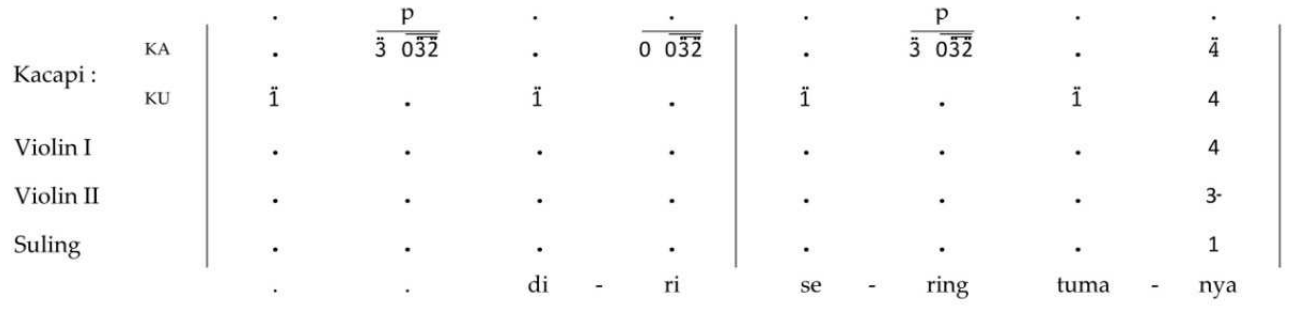

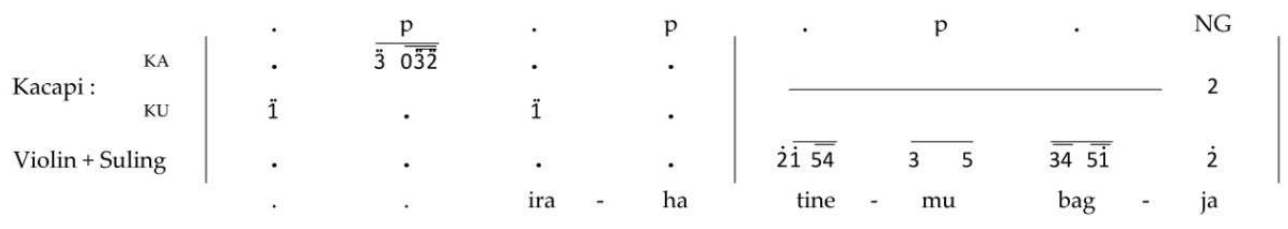

Naik Embat 2 Wilet

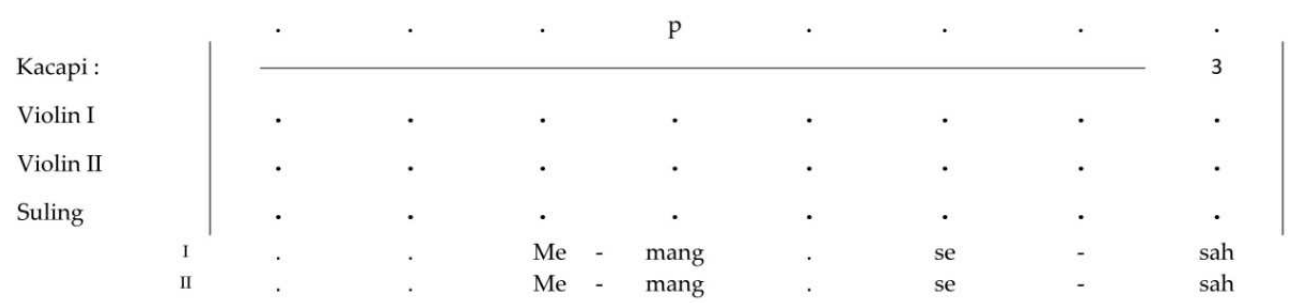



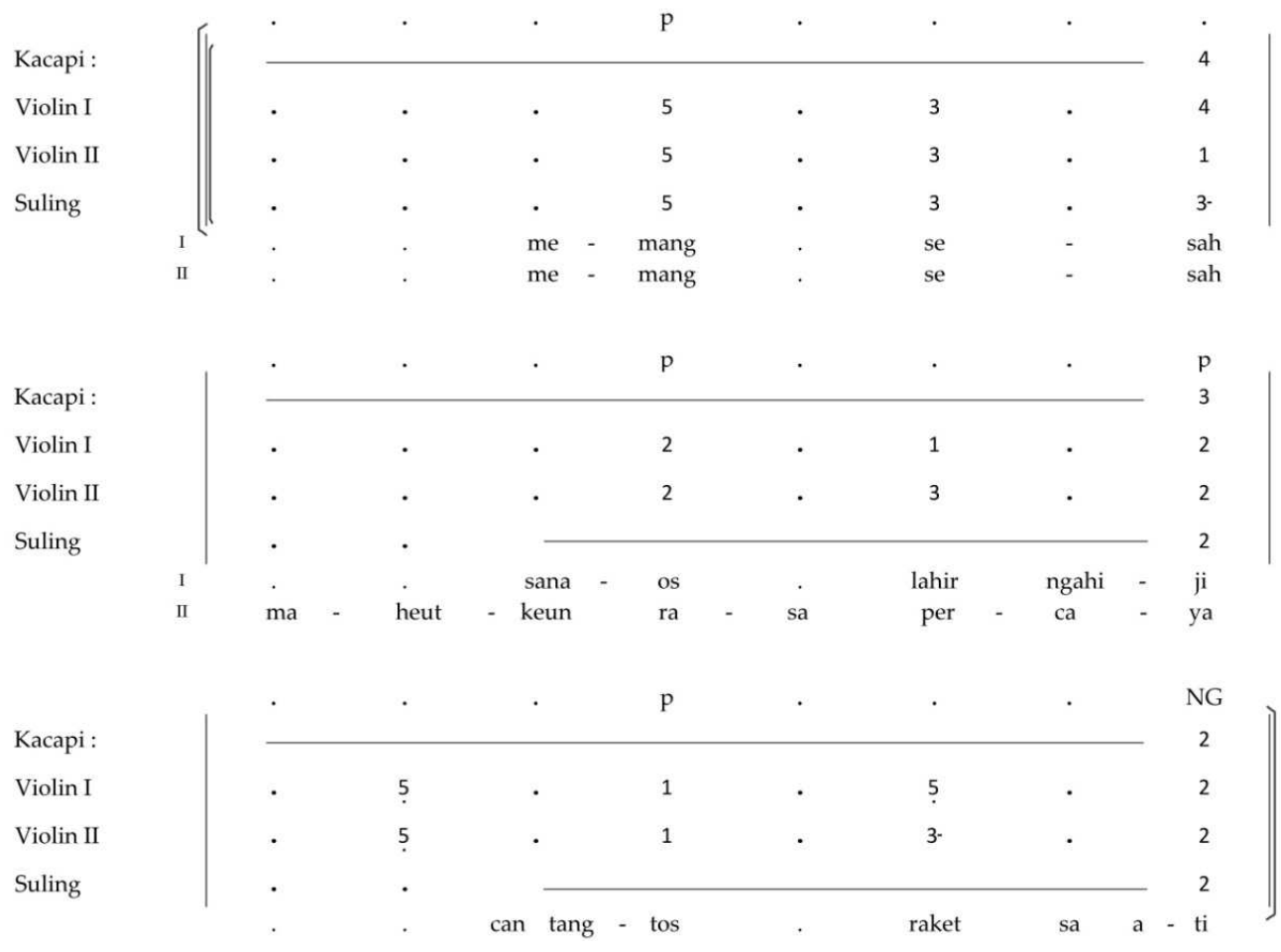

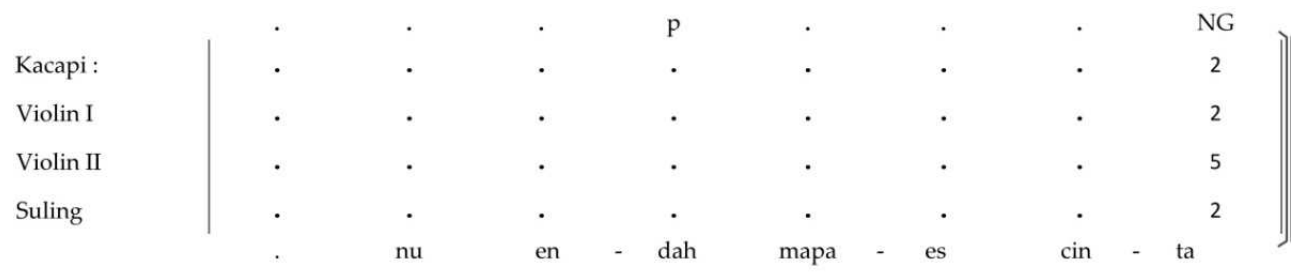

Gending Peralihan lagu : Laras Madenda $4=$ P, Embat Gancang

\begin{tabular}{|c|c|c|c|c|c|c|c|c|}
\hline \multirow[t]{3}{*}{ Kacapi : } & $\mathrm{KA}$ & 0 & $\overline{05}$ & . & 5 & 5 & 5 & 5 \\
\hline & $r u$ & 0 & 05 & . & 5 & 5 & 5 & 5 \\
\hline & & 0 & 02 & . & 2 & 2 & 2 & 2 \\
\hline Violin & & 0 & 05 & - & 5 & 5 & 5 & 5 \\
\hline Suling & & 0 & $\overline{05}$ & - & 5 & 5 & 5 & 5 \\
\hline
\end{tabular}

\section{Kuring Leungiteun}

Kuring Lengiteun diciptakan oleh Muhamad Yusuf Wiradiredja dan rumpaka oleh Zahir Zachri. Lagu Kuring Lengiteun pertama kali dibuat 
dalam kesenian celempungan, laras utama madenda 4=Panelu. Dalam konteks sajian pertunjukan Lengiteun, maka lagu tersebut diiringi menggunakan waditra utama kacapi, dilangkapi oleh waditra kendang, suling, goong, biola, dan perkusi latin. Aransemen kacapi dalam lagu Kuring Lengiteun penyaji mengambil dari Mp3 Kuring Lengiteun yang dipopulerkan oleh group Sanggita, sehingga sitem pelarasan pada kacapi yang didiaransemen kembali oleh Sanggita ada beberapa perubahan pada bagian senar bas.

Kacapi pada bagian bas (senar ke 11-20) dilaras dengan urutan nada sebagai berikut; senar ke 11 nada $1(\mathrm{da})$, ke 12 nada 2(mi), ke 13 nada 4-(Teu), ke 14 nada 5+(leu),ke 15 nada 5(la), ke 16 nada 1 (da), ke 17 nada 2(mi), ke 18 nada 3-(ni), ke 19 nada 3(na), ke 20 nada 4(ti), dan yang terakhir ke 21 nada 5(la) sehingga menghasilkan kesan nada diatonis.

\section{LEUNGITEUN}

irama $6 \backslash 8$

Laras Madenda $4=\mathrm{P}$

$$
\begin{aligned}
& \text { Kacapi : } \\
& \text { Kacapi II } \\
& \quad \text { KU } \\
& \text { Violin } \\
& \text { Suling }
\end{aligned}
$$




\begin{tabular}{|c|c|c|c|c|c|c|c|c|c|c|c|c|c|}
\hline \multirow{2}{*}{ Kacapi : } & KA & $\ddot{1}$ & 2 & 3. & $\overline{03}$ & 3- & 3- & $\overline{0 ~}$ & 3- & $\ddot{4}+$ & $\overline{04}$ & $\ddot{4}$ & $\ddot{4}$ \\
\hline & $\mathrm{KU}$ & 43 & 45 & 2 1 & 32 & 43 & 54 & 15 & 21 & 43 & 54 & 15 & 21 \\
\hline \multirow{3}{*}{ Kacapi II } & & $\overline{05}$ & . & $\overline{05}$ & $\overline{05}$ & . & $\overline{05}$ & $\overline{05}$ & . & $\overline{04}$ & $\overline{04}$ & . & 4 \\
\hline & $\gamma$ & 3 & 3 & 5 & 5 & 5 & 5 & 5 & 5 & 1 & 1 & 1 & 1 \\
\hline & $L$ & 1 & 1 & 1 & 1 & 1 & 1 & 1 & 1 & 4 & 4 & 4 & 4 \\
\hline Violin & & . & . & 1 & $?$ & 3 & 3 & 4 & 5 & 3 & 3 & 4 & 5 \\
\hline Suling & & . & . & 5 & $5+$ & 1 & 2 & $3-$ & 3 & 1 & 2 & $3-$ & 3 \\
\hline
\end{tabular}

\begin{tabular}{|c|c|c|c|c|}
\hline \multirow{2}{*}{ Kacapi : } & $\mathrm{KA}$ & $\ddot{4}+$ & $\ddot{4}$ & 5 \\
\hline & $\mathrm{KU}$ & $\overline{32}$ & $\overline{43}$ & 5 \\
\hline \multirow{3}{*}{ Kacapi II } & & $4^{+}$ & $4^{+}$ & 5 \\
\hline & & 1 & 1 & 2 \\
\hline & - & $4+$ & $4+$ & 5 \\
\hline Violin & I & 5 & 4 & 3 \\
\hline Violin & II & 3 & 3. & 2 \\
\hline
\end{tabular}
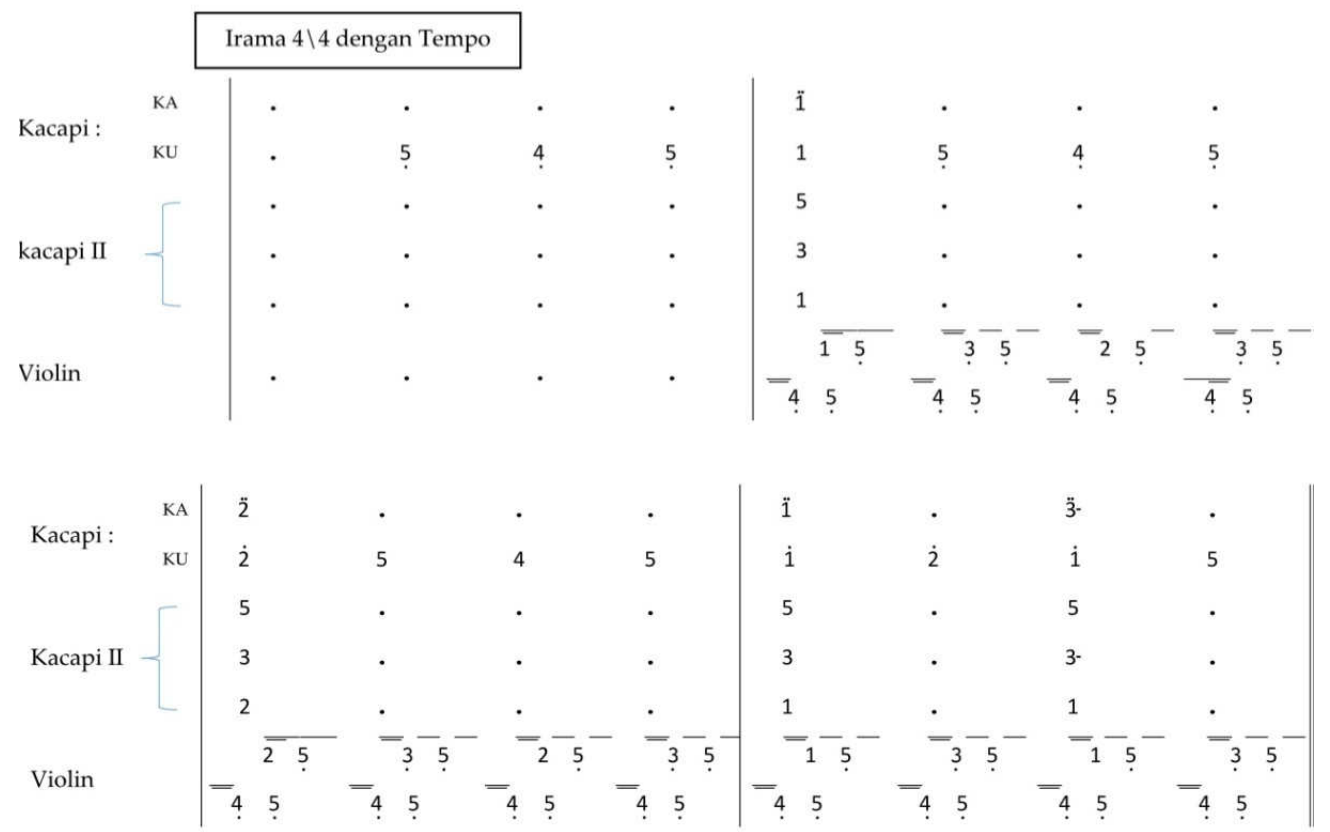

Motif Anggana Sekar

\begin{tabular}{|c|c|c|c|c|c|c|c|c|c|}
\hline \multirow{3}{*}{ Kacapi : } & KA & $\ddot{2}$ & . & . & - & . & - & . & $\ddot{1}$ \\
\hline & KU & 425425 & 425425 & 425425 & $425 \overline{425}$ & $4254 \overline{425}$ & 425425 & 425421 & 321321 \\
\hline & & 4 & . & . & . & . & . & . & . \\
\hline \multirow[t]{2}{*}{ Kacapi II } & & 2 & - & - & . & - & - & . & - \\
\hline & L & 4 & . & . & . & . & . & . & . \\
\hline \multirow[t]{2}{*}{ Violin } & & 4 & . & . & . & . & . & . & . \\
\hline & & . & . & . & . leu - n & teu & - & eun & . \\
\hline
\end{tabular}



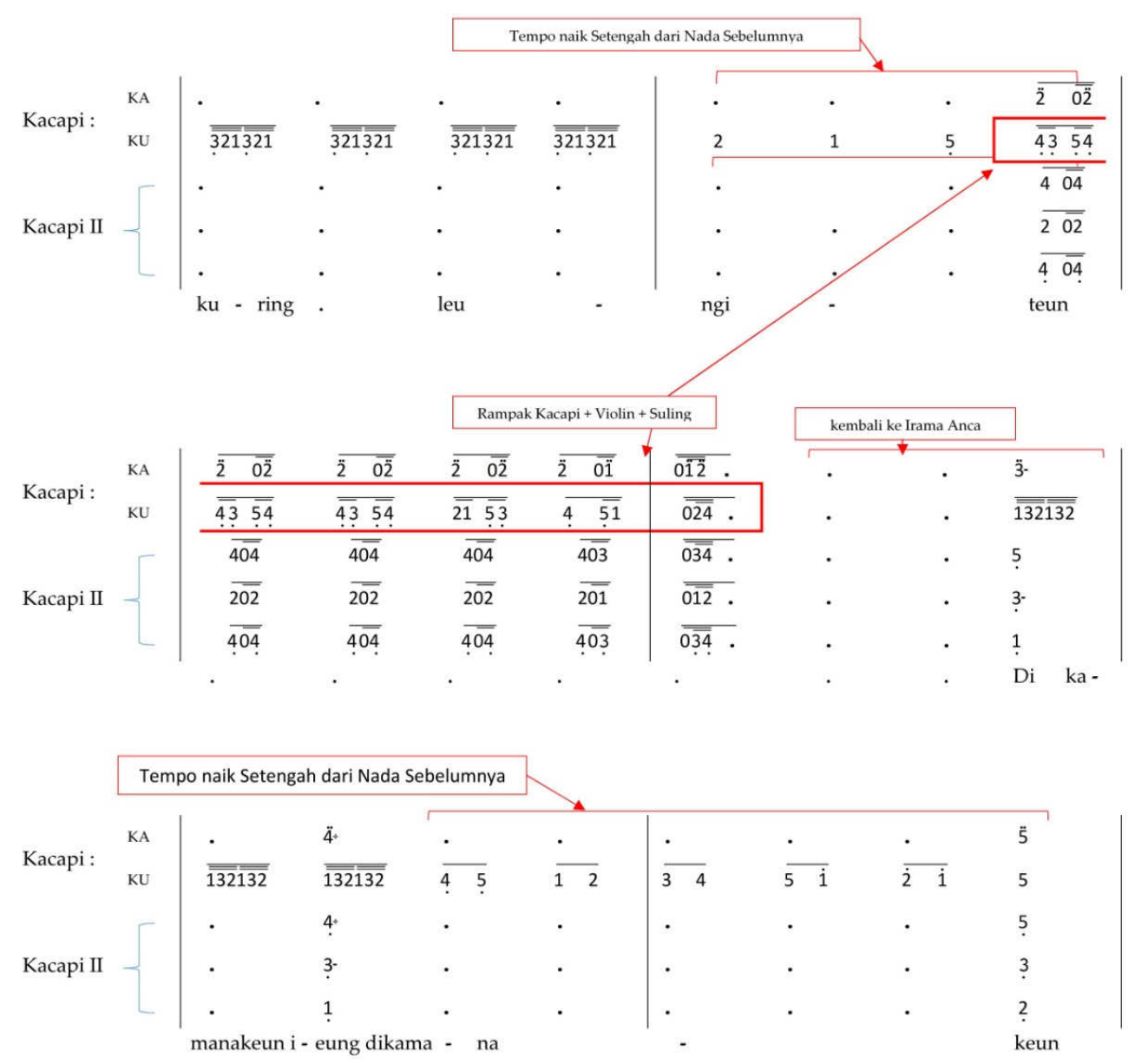

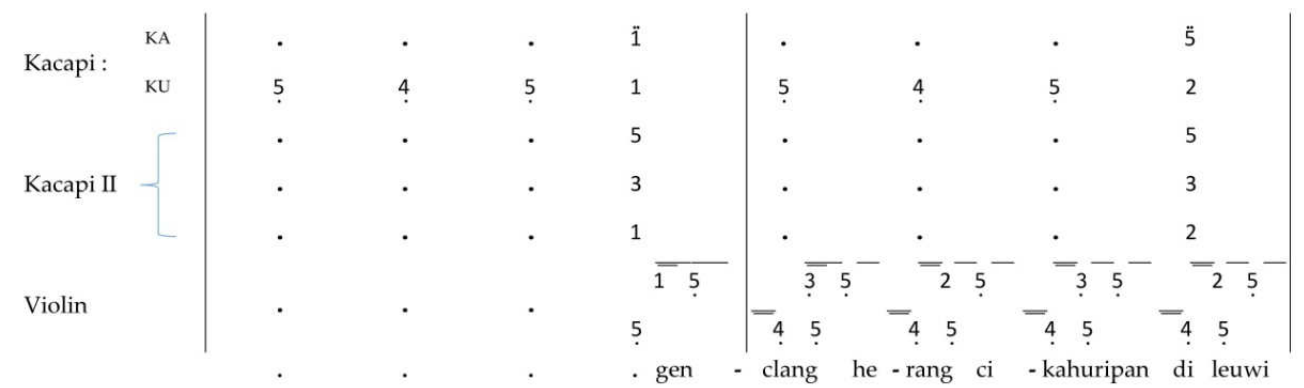

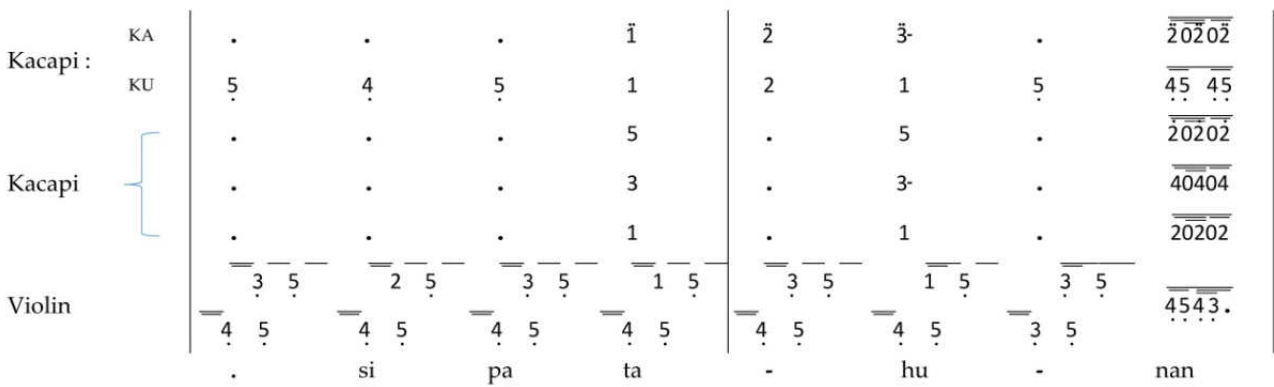




\begin{tabular}{|c|c|c|c|c|c|c|c|c|c|}
\hline \multirow[t]{2}{*}{ Kacapi } & KA & 0 & $\overline{\overline{101}} \overline{010}$ & $\overline{0 \quad 1}$ & $\overline{\overline{505}} 0 \overline{55}$ & 0 & $\overline{\overline{101}} \overline{010}$ & $\overline{0 \quad 1}$ & 5 \\
\hline & $\mathrm{KU}$ & . & $\overline{15} \overline{45}$ & . & $\overline{25} \quad \overline{45}$ & . & $\overline{15} \quad \overline{45}$ & . & $?$ \\
\hline \multirow{3}{*}{ Kacapi II } & & . & $\overline{50505}$ & . & $\overline{50505}$ & . & $\overline{50505}$ & . & 5 \\
\hline & ᄀ & . & 30303 & . & $\overline{30303}$ & . & $3 \overline{0303}$ & . & 3 \\
\hline & $c$ & . & $\overline{\overline{0101}}$ & . & $\overline{20202}$ & . & $\overline{\overline{10101}}$ & . & 2 \\
\hline \multicolumn{2}{|c|}{ Violin + Suling } & $0 \overline{54} \overline{3452}$ & $15 \overline{43}$. & $\overline{054} \overline{3451}$ & $25 \overline{\overline{34}}$. & $0 \overline{54} \overline{3452}$ & $\overline{15 \overline{43} .}$ & $\overline{05} \quad \overline{45}$ & $?$ \\
\hline
\end{tabular}

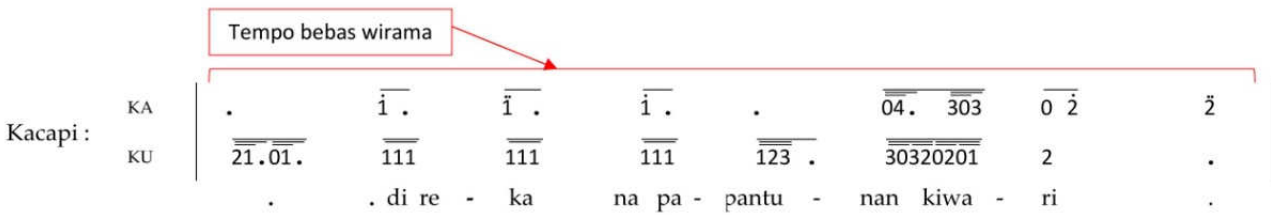

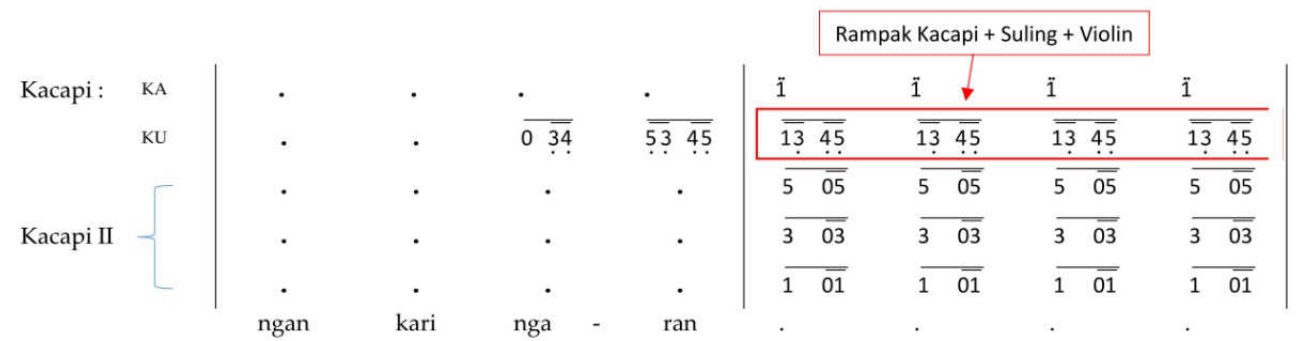

\begin{tabular}{|c|c|c|c|c|c|c|c|c|c|}
\hline \multirow[t]{2}{*}{ Kacapi : } & $\mathrm{KA}$ & \multicolumn{4}{|l|}{3.} & . & $\cdot$ & . & 5 \\
\hline & $\mathrm{KU}$ & $\overline{12} \quad 13$ & $24 \overline{32}$ & $32 \quad 32$ & $\overline{32} \overline{31}$ & 2 & . & . & $\overline{54} \quad \overline{32}$ \\
\hline & & 5 & . & . & - & . & $\cdot$ & $\cdot$ & . \\
\hline Kacapi II & \{ & 3- & . & . & . & . & . & . & . \\
\hline & L & 1 & . & . & . & . & . & . & . \\
\hline
\end{tabular}

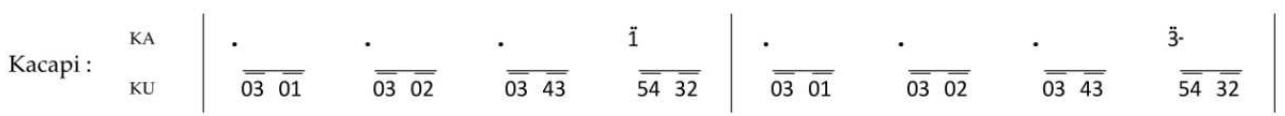

\begin{tabular}{|c|c|c|c|c|c|c|c|c|c|c|c|}
\hline \multirow{2}{*}{ Kacapi : } & KA & . & - & . & $\ddot{2}$ & \multicolumn{2}{|l|}{ - } & \multicolumn{2}{|l|}{ - } & . & 5 \\
\hline & $\mathrm{KU}$ & $\begin{array}{ll}03 \quad 01\end{array}$ & $\overline{03} \quad \overline{02}$ & $03 \quad 43$ & $42 \quad \overline{54}$ & 2 & 54 & 2 & 54 & . & $\begin{array}{l}54 \quad 32 \\
\end{array}$ \\
\hline Violin & I & . & . & . & . & . & & . & & . & 5 \\
\hline & II & . & . & . & . & . & & . & & . & 3 \\
\hline & III & . & . & . & . & . & & . & & . & 2 \\
\hline
\end{tabular}

\begin{tabular}{|c|c|c|c|c|c|c|c|c|c|}
\hline \multirow{2}{*}{ Kacapi : } & $\mathrm{KA}$ & - & . & . & $\ddot{i}$ & . & - & . & 3. \\
\hline & $\mathrm{KU}$ & $03 \quad \overline{01}$ & $\overline{03} \overline{02}$ & $03 \overline{43}$ & $\overline{54} \overline{32}$ & $\overline{03} \overline{01}$ & $\overline{03} \overline{02}$ & $\overline{03} \overline{43}$ & $\overline{54 \quad \overline{32}}$ \\
\hline Violin & I & - & - & - & 5 & 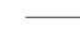 & & & 5 \\
\hline & II & - & - & - & 3 & - & - & & 3. \\
\hline & III & - & 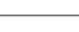 & 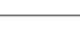 & 1 & - & 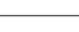 & 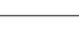 & 1 \\
\hline
\end{tabular}




\begin{tabular}{|c|c|c|c|c|c|c|c|c|c|c|}
\hline \multirow{2}{*}{ Kacapi : } & KA & . & . & . & $\ddot{2}$ & . & . & . & & $\overline{0 \overline{5}}$ \\
\hline & $\mathrm{KU}$ & $\overline{03} \overline{01}$ & $\overline{03} \overline{02}$ & $\overline{03} \overline{43}$ & $\overline{42} \overline{54}$ & $\overline{02} \overline{54}$ & $\overline{02} \overline{54}$ & . & $\overline{54}$ & $\overline{32}$ \\
\hline \multirow{3}{*}{ Violin } & I & & & & 2 & . & . & 0 & 3 & 4 \\
\hline & II & — & - & - & 5 & . & . & 0 & 3 & 4 \\
\hline & III & 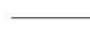 & 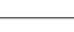 & 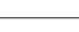 & 4 & . & . & 0 & 3 & 4 \\
\hline
\end{tabular}

\begin{tabular}{|c|c|c|c|c|c|c|c|c|c|c|c|c|c|c|}
\hline \multirow{2}{*}{ Kacapi : } & \multirow{2}{*}{$\begin{array}{l}\mathrm{KA} \\
\mathrm{KU}\end{array}$} & \multirow{2}{*}{$\begin{array}{ll}\overline{0} & 5 \\
0 & 4\end{array}$} & \multirow{2}{*}{\multicolumn{2}{|c|}{. }} & - & \multirow{2}{*}{\multicolumn{2}{|c|}{$\overline{1} \overline{01}$}} & \multirow{2}{*}{$\begin{array}{l}0 \\
.\end{array}$} & \multirow[t]{2}{*}{$\ddot{i}$} & \multirow{2}{*}{\multicolumn{2}{|c|}{. }} & \multirow{2}{*}{\multicolumn{2}{|c|}{. }} & $\overline{3-} \overline{03}-$ \\
\hline & & & & & 15 & & & & & & & & & 34 \\
\hline & & 0 & 0 & 5 & 0 & 0 & 5 & 0 & 5 & 0 & 5 & 0 & 5 & 0 \\
\hline Kacapi II & r & 3 & 3 & & 3 & 3 & & 3 & & 3 & & 3 & & $3-$ \\
\hline & L & 2 & 2 & & 2 & 1 & & 1 & & 1 & & 1 & & 1 \\
\hline Violin & & 04 & 5 & & 15 & . & & . & & . & & . & & 34 \\
\hline Suling & & 04 & 5 & & 15 & . & & . & & . & & . & & 3 \\
\hline
\end{tabular}

\begin{tabular}{|c|c|c|c|c|c|c|c|c|c|c|c|c|c|c|c|c|c|}
\hline \multirow{2}{*}{ Kacapi : } & \multirow{2}{*}{$\begin{array}{l}\mathrm{KA} \\
\mathrm{KU}\end{array}$} & \multirow{2}{*}{$\begin{array}{l}0 \\
0\end{array}$} & \multirow{2}{*}{$\frac{\overline{3}-}{4}$} & \multirow{2}{*}{\multicolumn{2}{|c|}{. }} & \multicolumn{2}{|l|}{. } & \multirow{2}{*}{\multicolumn{2}{|c|}{$\overline{\ddot{2} \quad \overline{02}}$}} & \multirow[t]{2}{*}{0} & \multirow[t]{2}{*}{$\ddot{2}$} & \multirow{2}{*}{\multicolumn{2}{|c|}{. }} & \multirow{2}{*}{\multicolumn{2}{|c|}{$\overline{21} \overline{5 ! 4}$}} & \multicolumn{2}{|c|}{$\begin{array}{ll}5 \quad \overline{05} \\
\end{array}$} \\
\hline & & & & & & 1 & 5 & & & & & & & & & 3 & 4 \\
\hline \multirow{3}{*}{ Kacapi II } & & 0 & 5 & 0 & 5 & 0 & 5 & 0 & 4 & 0 & 4 & 0 & 4 & & $\overline{4}$ & 0 & 5 \\
\hline & \} & 3. & & 3. & & 3- & & 2 & & 2 & & 2 & & 2 & & 3 & \\
\hline & L & 1 & & 1 & & 1 & & 4 & & 4 & & 4 & & 4 & & 2 & \\
\hline Violin & & 0 & 4 & 5 & & 1 & 5 & 2 & & . & & $\cdot$ & & $\overline{54}$ & 33. & $?$ & 3. \\
\hline Suling & & 0 & & 5 & & 1 & & 2 & & . & & . & & & 54 & 3 & 4 \\
\hline
\end{tabular}

\begin{tabular}{|c|c|c|c|c|c|c|c|c|c|c|c|c|c|c|c|c|c|}
\hline \multirow{3}{*}{ Kacapi : } & \multirow{2}{*}{$\begin{array}{l}\mathrm{KA} \\
\mathrm{KU}\end{array}$} & \multirow[t]{2}{*}{0} & $\overline{5}$ & \multicolumn{2}{|c|}{. } & \multicolumn{2}{|c|}{ - } & \multirow{2}{*}{\multicolumn{2}{|c|}{$\overline{1} \overline{01}$}} & \multirow[t]{2}{*}{0} & \multirow[t]{2}{*}{$\bar{i}$} & \multicolumn{2}{|l|}{. } & \multicolumn{2}{|l|}{ - } & \multicolumn{2}{|c|}{$\overline{3}-\overline{03}-$} \\
\hline & & & 4 & 5 & & 1 & 5 & & & & & . & & $\overline{21}$ & & 3 & 4 \\
\hline & & 0 & 5 & 0 & 5 & 0 & 5 & 0 & 5 & 0 & 5 & 0 & 5 & 0 & 5 & 0 & 5 \\
\hline Kacapi II & \{ & 3 & & 3 & & 3 & & 3 & & 3 & & 3 & & 3 & & 3- & \\
\hline & L & 2 & & 2 & & 2 & & 1 & & 1 & & 1 & & 1 & & 1 & \\
\hline Violin & & 0 & 3 & 3 & & 4 & 3 & . & & . & & . & & & 33- & $?$ & 3- \\
\hline Suling & & 0 & & 5 & & 1 & & . & & . & & . & & & 5. & 3 & 4 \\
\hline
\end{tabular}

\begin{tabular}{|c|c|c|c|c|c|c|c|c|c|c|c|c|c|c|c|c|c|}
\hline \multirow{3}{*}{ Kacapi : } & \multirow{2}{*}{$\begin{array}{l}\mathrm{KA} \\
\mathrm{KU}\end{array}$} & \multirow{2}{*}{$\begin{array}{l}0 \\
0\end{array}$} & \multirow{2}{*}{$\frac{3}{4}$} & \multirow{2}{*}{\multicolumn{2}{|c|}{. }} & \multicolumn{2}{|l|}{. } & \multirow{2}{*}{\multicolumn{2}{|c|}{$\begin{array}{l}2 \\
2\end{array}$}} & \multirow{2}{*}{\multicolumn{2}{|c|}{$\begin{array}{l}\ddot{1} \\
1\end{array}$}} & \multirow{2}{*}{\multicolumn{2}{|c|}{$\begin{array}{l}\dot{5} \\
5 \\
\end{array}$}} & \multirow{2}{*}{\multicolumn{2}{|c|}{$\begin{array}{l}i \\
3\end{array}$}} & \multirow{2}{*}{\multicolumn{2}{|c|}{$\begin{array}{l}2 \\
4\end{array}$}} \\
\hline & & & & & & 1 & 5 & & & & & & & & & & \\
\hline & r & 0 & 5 & 0 & 5 & 0 & 5 & 0 & 5 & 0 & 5 & 0 & 5 & 0 & 5 & 0 & 5 \\
\hline \multirow[t]{2}{*}{ Kacapi II } & & 3- & & 3- & & $3-$ & & 2 & & 2 & & 2 & & 2 & & 2 & \\
\hline & L & 1 & & 1 & & 1 & & 4. & & 4 & & 4. & & 4. & & 1 & \\
\hline Violin & & 0 & $3-$ & 3 & & 4. & 3 & 4 & & 3 & & 3. & & 1 & & $?$ & \\
\hline Suling & & 0 & 4 & 5 & & 1 & 5 & 2 & & 1 & & 5 & & 3 & & 4 & \\
\hline
\end{tabular}




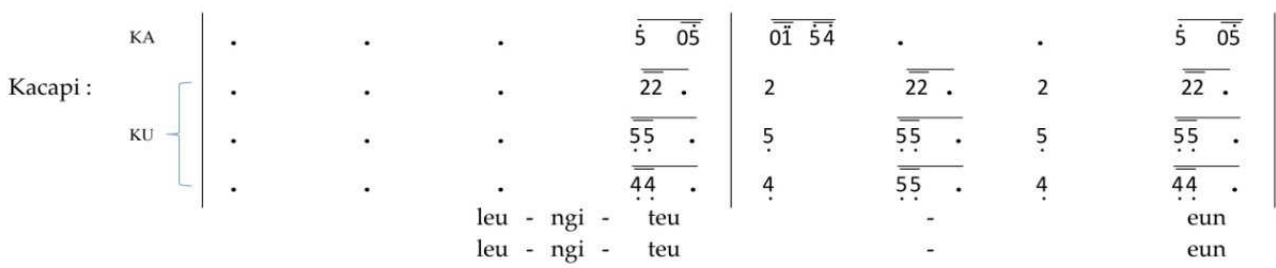

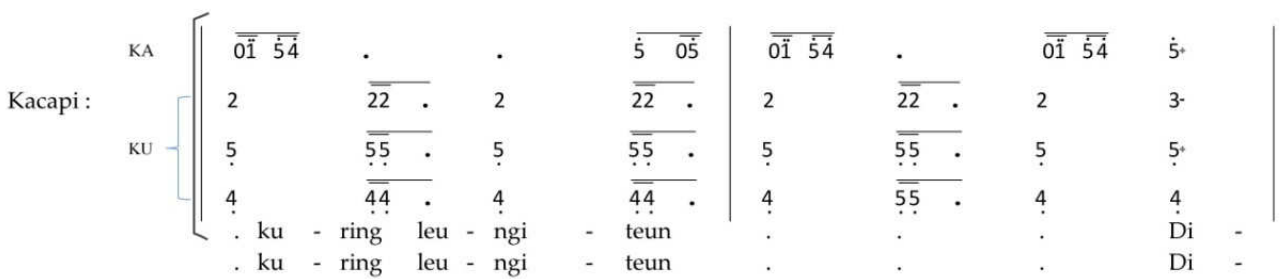

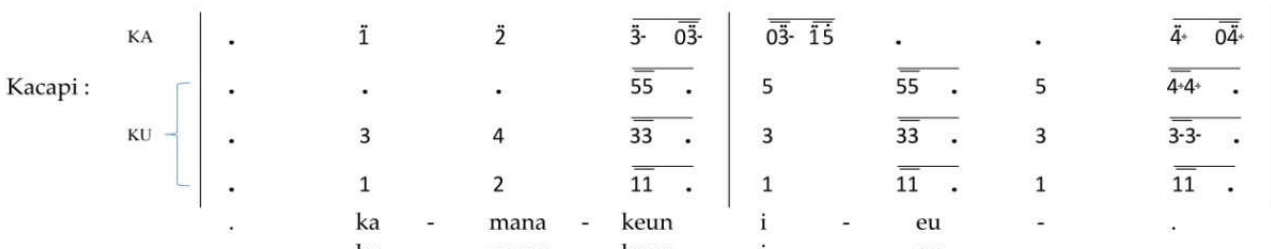

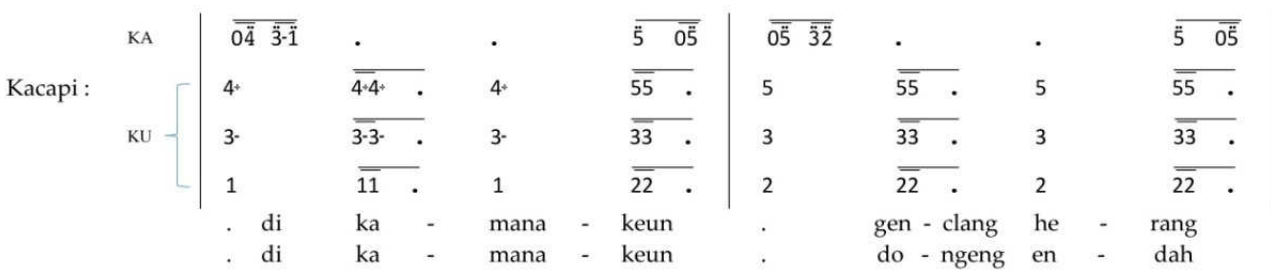

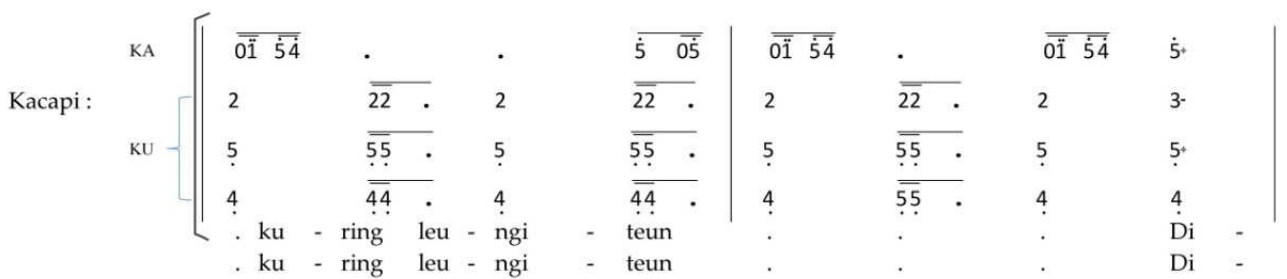

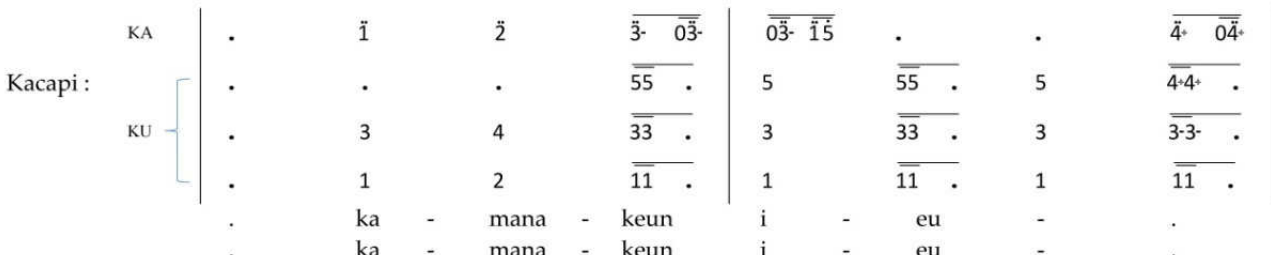




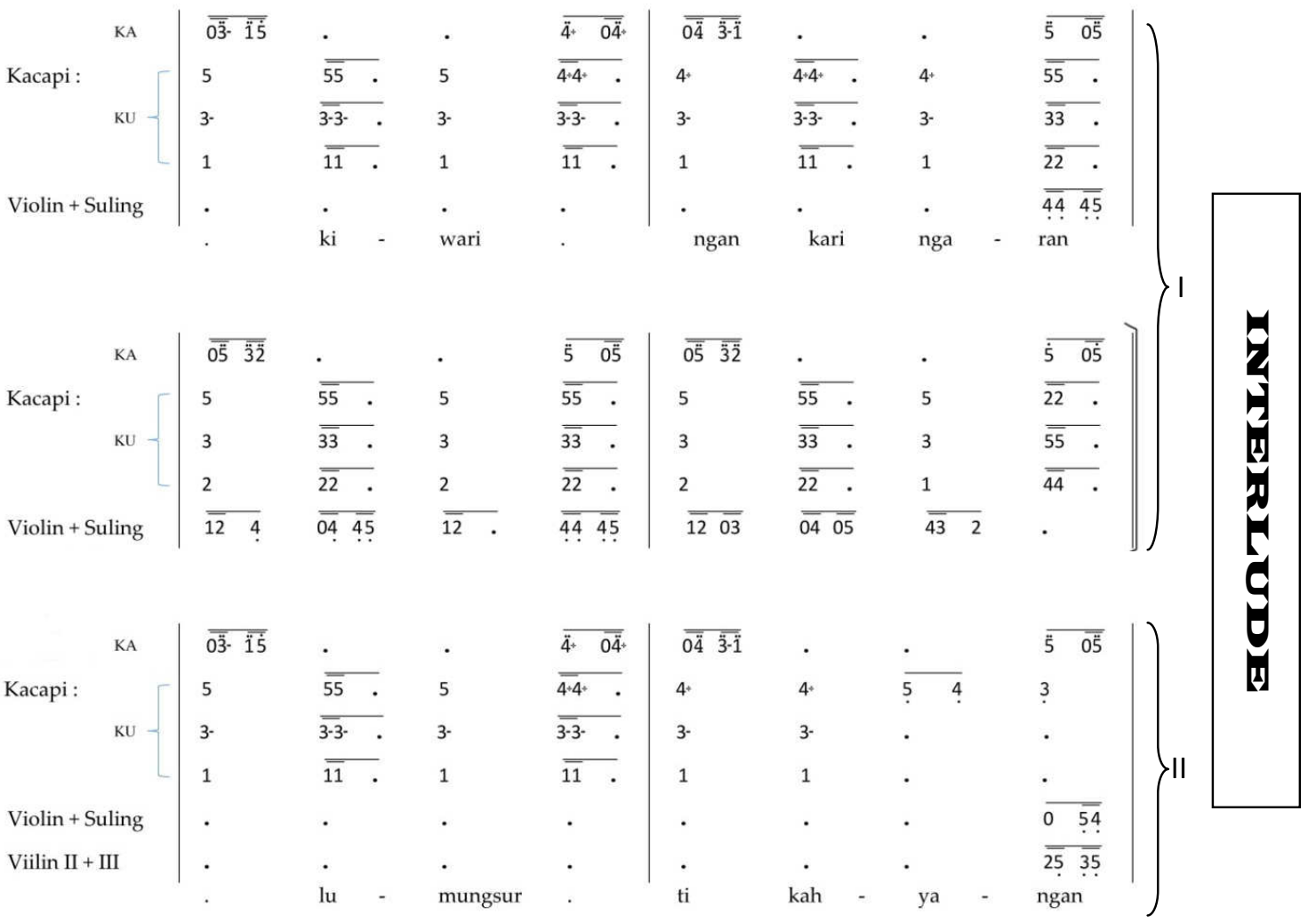

\begin{tabular}{|c|c|c|c|c|c|c|c|c|}
\hline \multirow{2}{*}{$\begin{array}{ll} & \text { KA } \\
\text { Kacapi : } & \\
& \mathrm{KU}\end{array}$} & $\overline{50} \quad \overline{05}$ & $\overline{505}$ & $\overline{5 \quad \overline{05}}$ & $\overline{5}+\overline{05}+$ & $\overline{\dot{5}+} \quad \overline{0 \dot{5}}$ & $\overline{5}+\overline{05}$ & $\overline{5}+\overline{05}$ & $\overline{10 \overline{1}}$ \\
\hline & . & . & 2 & 434. & . & . & $\overline{03} \overline{45}$ & $2 \overline{43}$ \\
\hline \multirow{3}{*}{ Kacapi II } & $\overline{05} \overline{05}$ & $\overline{05} \quad \overline{05}$ & $\overline{05} \overline{05}$ & $\overline{05}+0 \overline{05}$ & $\overline{05}+\overline{05}+$ & $\overline{05}+\overline{05}$ & $\overline{05}+\overline{05}$ & $\overline{0505}$ \\
\hline & 3 & 3 & 3 & 4 & 4 & 4 & 4 & 3 \\
\hline & 2 & 2 & 2 & $3-$ & $3-$ & $3-$ & 3 & 1 \\
\hline Violin + Suling & 3 & $0 \quad 54$ & $32 \quad 3-3$ & $4 \quad 5+5$ & 4 & $0 \quad 5+5$ & 4345 & $23-35$ \\
\hline Violin II + III & $\overline{35} \quad \overline{35}$ & $\overline{25} \quad \overline{35}$ & $3 \overline{35} \quad \overline{35}$ & $3-5+45^{+}$ & $4 \overline{45}+4+$ & $3-5+4 \overline{5}$ & $\overline{45}+45$ & $15+55$ \\
\hline
\end{tabular}

\begin{tabular}{|c|c|c|c|c|c|c|c|c|}
\hline KA & $\overline{101 \overline{1}}$ & $\overline{10 \overline{1}}$ & $\overline{1} \ddot{2}$ & $\overline{3}-\overline{03}-$ & $\overline{3-0 \ddot{3}}-$ & $\overline{4.0 \overline{4}}$ & $\overline{4.0 \overline{4}}$ & $\overline{5} \overline{0 \overline{5}}$ \\
\hline $\mathrm{KU}$ & . & . & . & 21592 & 1421 & 301 & 2343 & $5 \quad \overline{43}$ \\
\hline \multirow{3}{*}{ Kacapi II } & $05 \quad 05$ & $\overline{05 \quad 05}$ & $05 \quad 05$ & $05 \quad 05$ & $\overline{05 \quad 05}$ & $04+04$ & $\overline{04}+04$ & $05 \quad 05$ \\
\hline & 3 & 3 & 3 & $3-$ & $3-$ & $3-$ & $\overline{3-3-}$ & 3 \\
\hline & 11 & 1 & 1 & 11 & 1 & 1 & 1 & 2 \\
\hline Violin + Suling & $02+3-3$ & 5 & $5+35$. & 21592 & $14 \quad 21$ & $3 \quad 05$ & 43.21 & $52 \quad 55$ \\
\hline Violin II + III & $5 \overline{5}+5$ & 15. $5 \overline{5}$ & $\overline{55}+\overline{12}$ & 3- & 1 & 4 & 4 & $25 \quad 35$ \\
\hline
\end{tabular}




\begin{tabular}{|c|c|c|c|c|c|c|c|c|}
\hline \multirow{2}{*}{ Kacapi : } & $\overline{5} \quad \overline{05}$ & $\overline{5} \overline{05}$ & $\overline{5 \quad \overline{05}}$ & $\overline{5+} \overline{05}$ & $\overline{\dot{5}+} \overline{0 \overline{5}}+$ & $\overline{\dot{5}+} \overline{05}$ & $\overline{5}+\overline{05}$ & $\overline{1} \overline{01}$ \\
\hline & . & . & $?$ & $\overline{43} \overline{4}$. & . & . & $\overline{03} \overline{45}$ & $\begin{array}{l}2 \quad \overline{3} \\
4\end{array}$ \\
\hline & $\overline{05} \overline{05}$ & $\overline{05} \overline{05}$ & $\overline{05} \overline{05}$ & $\overline{05}+\overline{05}$ & $\overline{05}+\overline{05}+$ & $\overline{05}+\overline{05}+$ & $\overline{05}+\overline{05}$ & $\overline{05} \quad \overline{05}$ \\
\hline \multirow[t]{2}{*}{ Kacapi II } & 33 & 3 & 3 & 4 & 4 & $\begin{array}{ll}4 & 4\end{array}$ & 4 & 3 \\
\hline & 22 & 2 & 2 & $3-$ & 3- & 3- 3- & 3- & 1 \\
\hline Violin + Suling & $25 \quad 5+2$ & 5 & $32 \quad 3-3$ & $4 \quad 5+5$ & 4 & $0 \quad 5+5$ & 4345 & 23. \\
\hline Violin II + III & 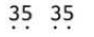 & $25 \quad 35$ & בִ & 3-5+5 4. & $45+45^{+}$ & $3-5+4 \cos ^{+}$ & $45^{+}+4 \underbrace{+}$ & $15+5$ \\
\hline \multirow{2}{*}{ Kacapi : } & $\overline{10 \overline{1}}$ & $\overline{1} \overline{0 \overline{1}}$ & $\bar{i}$ & $\overline{3}-\overline{0 \overline{3}}-$ & $\overline{3}-\overline{0 \overline{3}}$. & $\overline{4^{*}+\overline{0 \overline{4}}}$ & $\overline{4^{*}+\overline{0 \ddot{4}}}$ & $\overline{5} \quad \overline{05}$ \\
\hline & $\cdot$ & $\cdot$ & $\cdot$ & 21592 & $14 \overline{21}$ & 3215 & 2343 & $?$ \\
\hline & $05 \quad \overline{05}$ & $\overline{05} \overline{05}$ & $05 \quad \overline{05}$ & 0505 & $\overline{05} \quad \overline{05}$ & $\overline{04}+\overline{04}$ & $\overline{04}+\overline{04}$ & 5 \\
\hline \multirow[t]{2}{*}{ Kacapi II } & 3 & 3 & 3 & $3-$ & $3-$ & 3. & 3- & 3 \\
\hline & 1 & 1 & 1 & 11 & 1 & $\begin{array}{ll}1 & 1\end{array}$ & 1 & 2 \\
\hline Violin + Suling & $02 * 3-3$ & 5 & • & 21592 & 14.21 & 3215 & 4321 & 5 \\
\hline Violin II + III & $55+55$ & $\overline{15}+\overline{55}$ & $\overline{55}+12$ & 3. 2 & 1 & 3 & 4 & 2 \\
\hline
\end{tabular}

\begin{tabular}{|c|c|c|c|c|c|c|c|c|c|c|c|c|c|}
\hline \multicolumn{3}{|c|}{ Coda Masuk Lagu } & & & & \multirow[b]{2}{*}{$\overline{505}$} & \multirow[b]{2}{*}{0} & \multirow[b]{2}{*}{$\overline{5}$} & \multirow[b]{2}{*}{. } & & & & \\
\hline \multirow{2}{*}{ Kacapi : } & $\mathrm{KA}$ & 0 & $\overline{5}$ & . & . & & & & & & \multicolumn{2}{|l|}{. } & $\overline{2} \overline{0 \overline{5}}$ \\
\hline & $\mathrm{KU}$ & 4 & & 3 & $?$ & 5 & 1 & & \multicolumn{2}{|c|}{23} & 4 & 5 & $\overline{4404}$ \\
\hline \multirow{3}{*}{ Kacapi II } & & . & & . & . & 5 & . & & . & & . & & 2202 \\
\hline & & . & & . & . & 3 & . & & . & & . & & 4404 \\
\hline & L & . & & . & $\cdot$ & 2 & $\cdot$ & & . & & . & & . \\
\hline \multicolumn{2}{|c|}{ Violin + Suling } & . & & . & . & . & 1 & & $?$ & 3 & 4 & 5 & 4 \\
\hline \multirow{2}{*}{\multicolumn{2}{|c|}{ Violin II + III }} & . & & · & $\cdot$ & . & . & & . & & . & & 2 \\
\hline & & & & & & & & & & & Gus & & $\mathrm{ti}$ \\
\hline
\end{tabular}

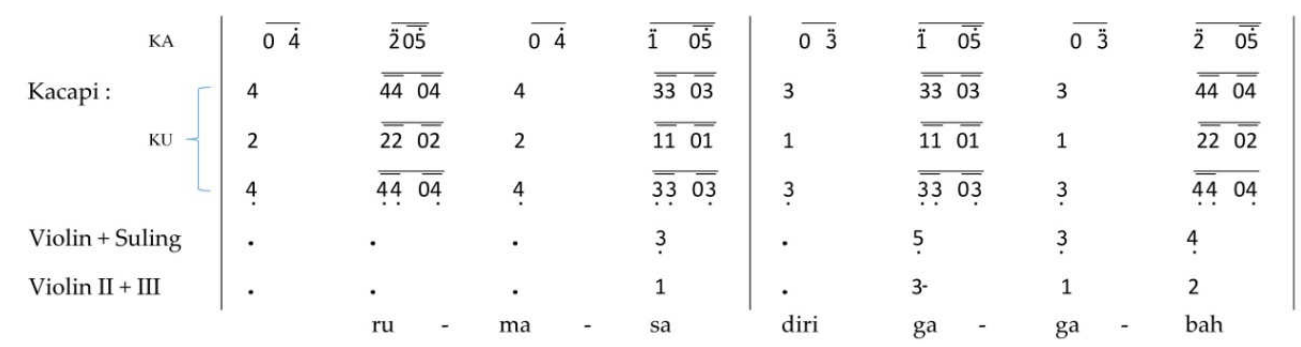

\begin{tabular}{|c|c|c|c|c|c|c|c|c|c|c|c|c|c|c|}
\hline $\mathrm{KA}$ & 0 & $\overline{\dot{4}}$ & $\overline{2}$ & $\overline{0 \overline{5}}$ & 0 & $\dot{4}$ & $\overline{\ddot{2} \quad \overline{0 \dot{5}}}$ & 0 & $\overline{\dot{4}}$ & $\bar{z}$ & $\overline{0 \overline{5}}$ & 0 & $\overline{\dot{4}}$ & $\overline{3}-\overline{01}$ \\
\hline Kacapi : & 4 & & $\overline{44}$ & $\overline{04}$ & 4 & & $\overline{\overline{44} \quad \overline{04}}$ & 4 & & $\overline{44}$ & $\overline{04}$ & 4 & & $\overline{55} \overline{05}$ \\
\hline $\mathrm{KU}$ & 2 & & 22 & 02 & 2 & & 2202 & 2 & & 22 & 02 & 2 & & 3-3-03- \\
\hline & 4 & & $\overline{44}$ & 04 & 4 & & $44 \quad 04$ & 4 & & 33 & 03 & 4 & & $\overline{11} \quad \overline{01}$ \\
\hline Violin + Suling & . & & . & & . & & . & . & & . & & 0 & $\overline{34}$ & 5 \\
\hline Violin II + III & . & & . & & . & & . & $\cdot$ & & · & & 0 & 12 & $3-$ \\
\hline
\end{tabular}




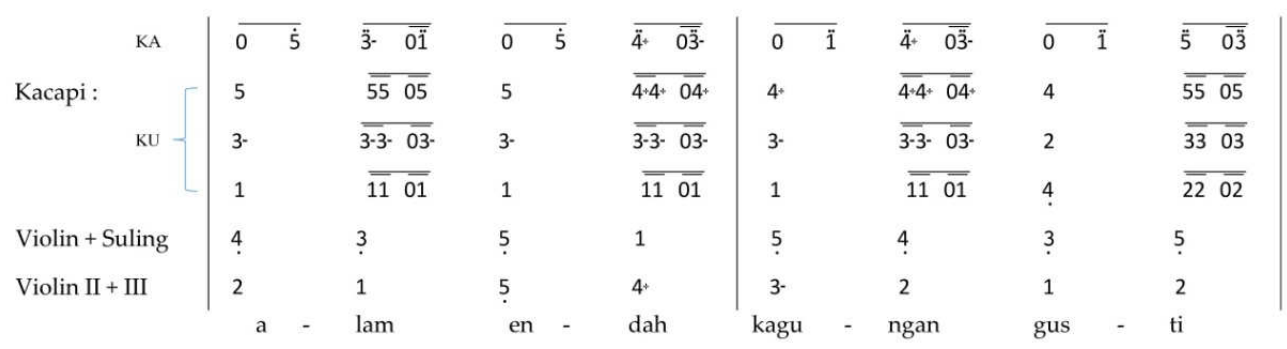

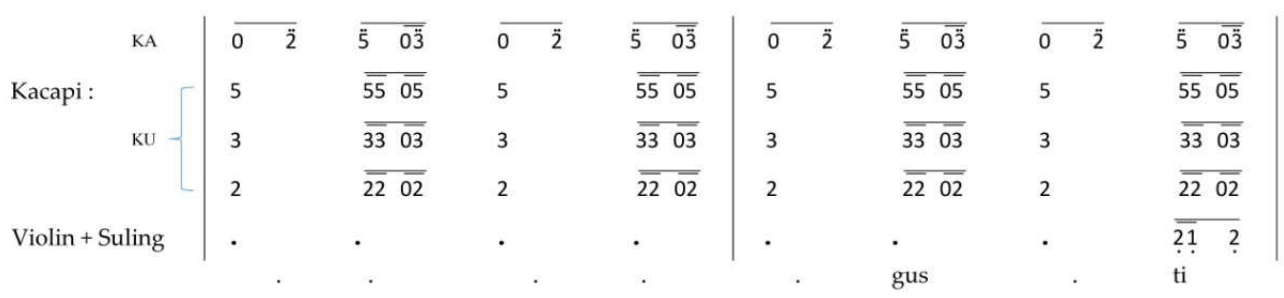

\begin{tabular}{l|lllllll|lllll} 
Kacapi : \\
Violin + Suling
\end{tabular}
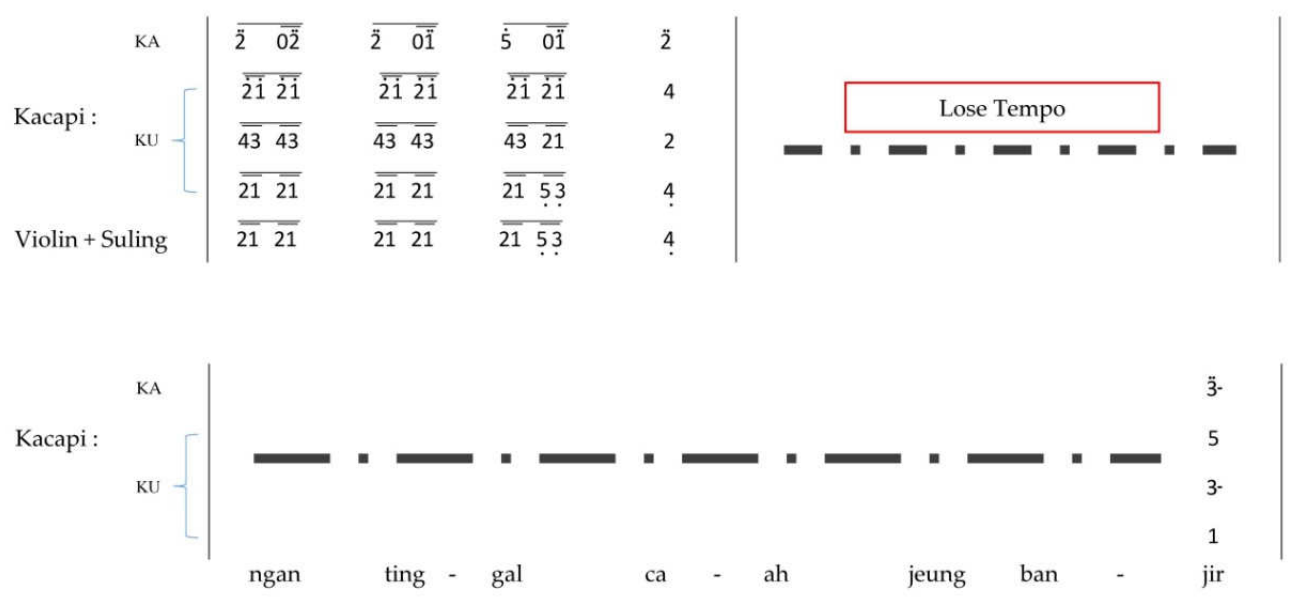


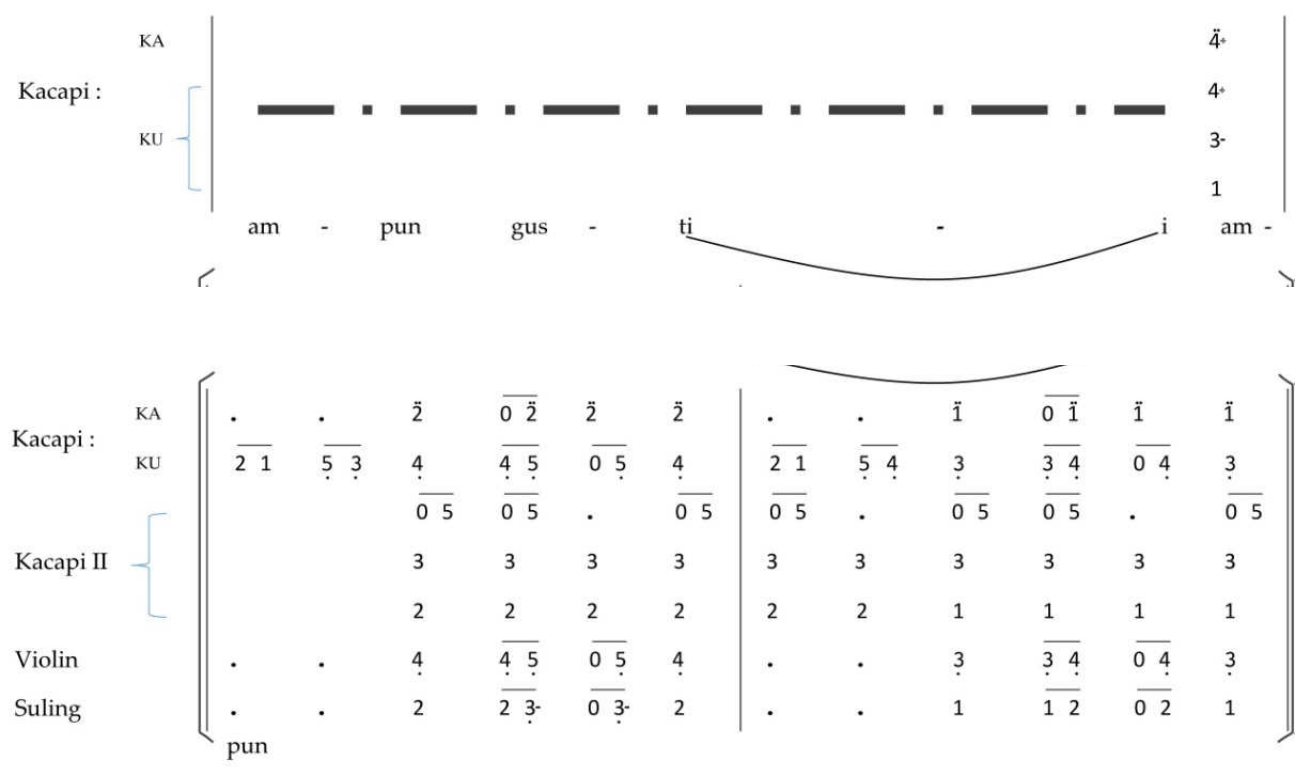

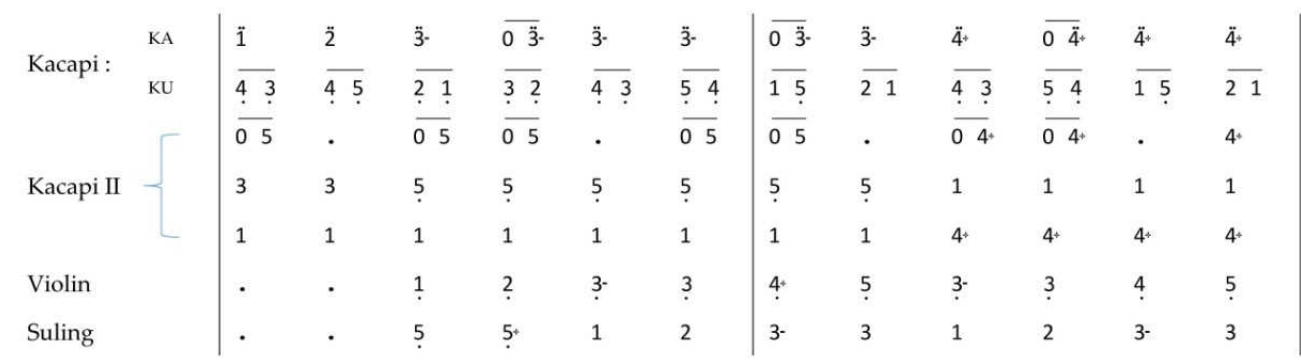

\begin{tabular}{|c|c|c|c|c|}
\hline \multirow{2}{*}{ ́acapi : } & $\mathrm{KA}$ & $\ddot{4}$ & $\ddot{4}$ & 5 \\
\hline & $\mathrm{KU}$ & $\overline{32}$ & $\overline{43}$ & 5 \\
\hline \multirow{3}{*}{ ́acapi II } & & $4^{+}$ & $4^{+}$ & 5 \\
\hline & $\prec$ & 1 & 1 & 2 \\
\hline & - & 4 & $4^{+}$ & 5 \\
\hline Tiolin & I & 5 & 4 & 3 \\
\hline Tiolin & II & 3 & $3-$ & 2 \\
\hline
\end{tabular}




\section{BAB IV \\ KESIMPULAN}

Kacapi merupakan alat musik sunda yang dimainkan sebagai alat musik utama untuk mengiringi lagu. Kata kacapi dalam bahasa Sunda juga merujuk kepada tanaman sentul, yang dipercaya kayunya digunakan untuk membuat alat musik kacapi. Kacapi berfungsi untuk mengiringi lagu-lagu sunda di antaranya lagu tembang sunda cianjuran, celempungan, setra karesmen, gending karesmen atau sendratari dan kawih wanda anyar. Selain itu sering dipergunakan untuk mengiringi pada acara ngaras, siraman, serta ngeuyeuk seureuh pada acara pesta perniakahan, dan hiburan pada perayaan lainnya. Seiring pada zamannya kini kacapi sering juga digunakan pada lagu-lagu bernada diatonis atau lagu - lagu ganre lainnya yang memang dibutuhkan oleh masyarakat sekitar.

Dalam menjalankan sebuah seni pertunjukan, tentu memerlukan langkah-langkah yang tepat. Seperti memerlukan ide pementasan, menentukan jenis pementasan, menentukan tempat pementasan, memperkirakan keadaan sumber daya manusia (SDM), alat, bahan, dan biaya. Menyusun kebutuhan alat dan bahan, serta menyusun jadwal kegiatan (schedule). 
Dari banyaknya cabang seni, seni pertunjukan merupakan salah satu seni yang dapat menyampaikan informasi melalui audio dan visual, yang membuat pesan, yang didalamnya dapat lebih mudah untuk sampai kepada penonton. Karenanya, penting seni pertunjukan untuk lebih dikenal dan meluas untuk masyarakat umum untuk mencintai dan mengenal secara mendalam mengenai seni pertunjukan. 


\section{DAFTAR FUSTAKA}

Coolsma, 1913. Soendaneesch-Hollandsch Worrdenboek. Leiden: .W.Sijthoff's Uitgeversmaatschappij.

Komala, Icuh. 2015. "Kompetensi Enoch Atmadibrata Pada Kesenian Jawa Barat." Jurnal Ilmiah Seni \& Budaya Pantun Vol. I No. 1. Bandung: Pascasarjana ISBI, 16-33.

Nugraha, Geri Kurnia. 2017. “Skripsi Asih Katungkul Ku Pati.” Skripsi Penyajian Karya Seni. Bandung: ISBI Bandung.

Ruswandi, Tardi. 2008. Bahan Ajar Kacapi Siter. Bandung: Sunan Ambu Press STSI Bandung.

Ruswandi, Tardi. Asep Nugraha \& Dody Satya Ekagustdiman. 2013. "Ragam Alat Musik Petik Tradisional Sunda." Hasil Penelitian Fundamental. Bandung: Sekolah Tinggi Seni Indonesia (STSI).

Ruswandi, Tardi. 2017. Kawih Sunda karya mang Kokoan. Bandung: Sunan Ambu Press STSI.

Sumantri, Maman., Atjep Djamaludin, Achmad Patoni, Moch Koerdi, MO Keosman, \& Epa Sjafei. 1985. Kamus Sunda Indonesia. Jakarta: Pusat Pengembangan dan Pembinaan Bahasa Departemen Pendidikan dan Kebudayaan.

Supanggah, Rahayu, 2007 . Bothekan Karawitan "Garap": ISI press Surakarta Supanggah, Rahayu. 2015. “Konsep Garap: Salah Satu Model Pendekatan Kajian Musik Nusantara"dalam Metodelogi Kajian Tradisi Lisan: Edisi Revisi. Jakarta: Yayasan Pustaka Obor Indonesia. 


\section{GLOSARIUM}

A

Amardawa Lagu Fungsi instrumen musik sebagai pembawa melodi lagu.

Ancaran wirahma Fungsi instrumen musik Sunda sebagai pengatur tempo dan irama lagu.

Arkuh Lagu Fungsi instrumen musik sebagai pembawa kerangka lagu.

B

Bubuka

Sajian musik instrumental yang ditempatkan sebagai musik Pembukaan

D

Degung Laras atan scale pada karawitan Su

G

Gamelan kelompok instrumen xylophene dari bahan perunggu

Gending Melodi tetabuhan yang berasal dari berbagai alat musik yang menjalin satu kesatuan utuh berdasarkan peranannya masing-masing

Geulenyu Bagian intro atau interlude dalam sebuah lagu yang dimainkan tanpa vokal.

Goong

I

Irama merdika Jenis lagu yang tidak terikat oleh tempo dan ketukan.

Irama tandak Jenis lagu yang terikat oleh tempo dan ketukan. 


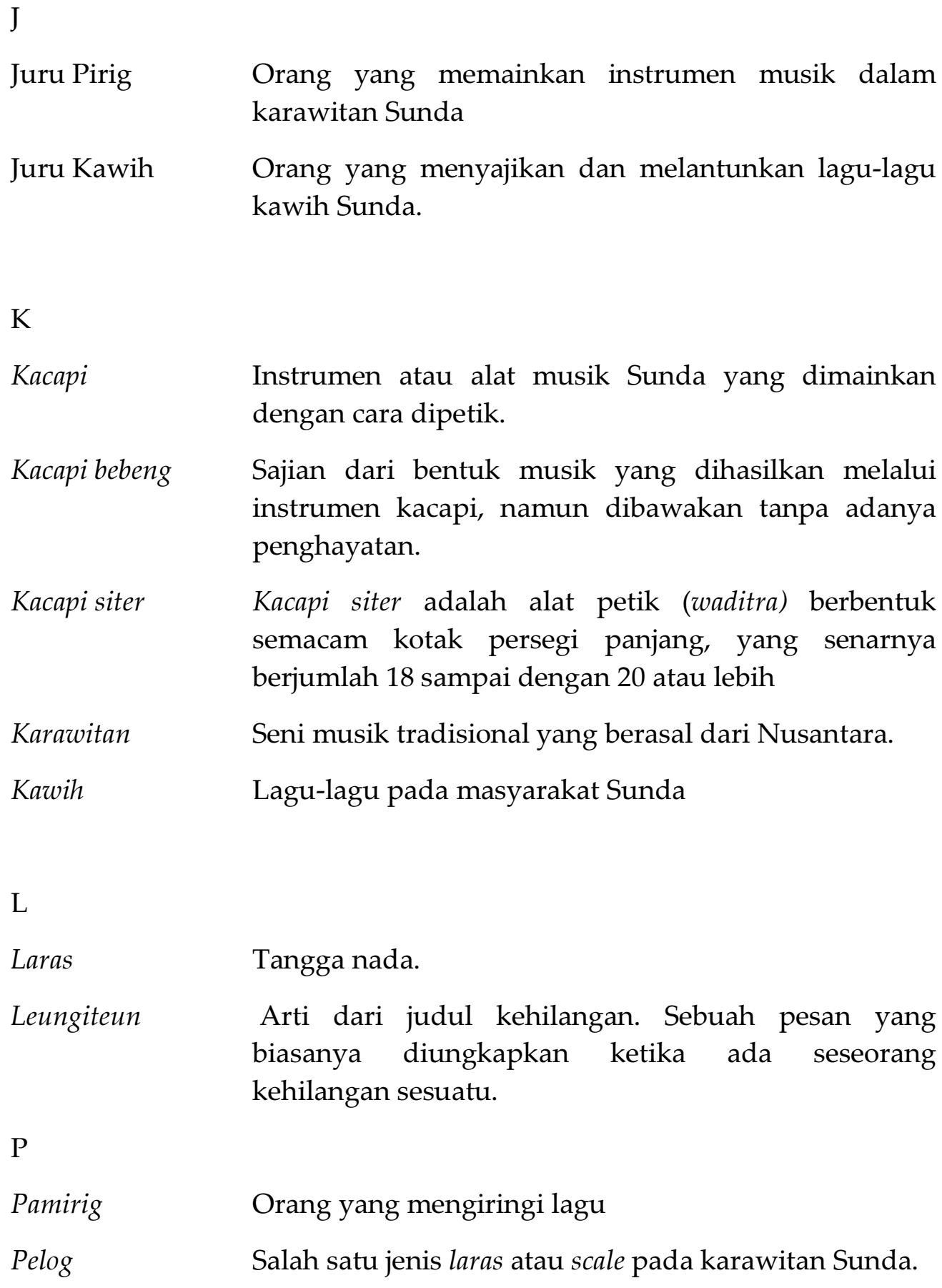

L

Laras Tangga nada.

Leungiteun Arti dari judul kehilangan. Sebuah pesan yang biasanya diungkapkan ketika ada seseorang kehilangan sesuatu.

P

Pamirig Orang yang mengiringi lagu

Pelog Salah satu jenis laras atau scale pada karawitan Sunda. 
$\mathrm{R}$

Rebab

Rincik

Rumpaka

S

Sekar

Sekar gending

Sorog

Suling

W

Wanda

Wanda Anyar
Alat musik karawitan Sunda yang berasal dari Jawa, dimainkan dengan cara digesek.

Alat musik atau waditra Sunda yang bentuknya seperti kacapi hanya saja bentuknya lebih kecil dan dimainkan dengan cara dipetik.

lirik.

Suara manusia atau vokal.

Perpaduan sajian antara nyanyian yang dihasilkan suara munusia dengan iringan tetabuhan yang dihasilkan instrumen alat musik karawitan

Salah satu jenis laras atau scale pada karawitan Sunda

Alat musik karawitan Sunda yang terbuat dari bambu dimainkan dengan cara ditiup.

Istilah yang ditujukan untuk mengkategorisasikan lagu-lagu sesuai lagu-lagu sesuai dengan karakter setiap lagu.

seni pertunjukan karawitan Sunda merupakan penyebutan wajah baru atau sebuah sebutan untuk garapan karawitan gaya baru yang diciptakan Koko Koswara 